\title{
Influence of Phosphorus and Cell Geometry on the Fractionation of Sulfur Isotopes by Several Species of Desulfovibrio during Microbial Sulfate Reduction
}

OPEN ACCESS

Edited by:

William Sunda,

University of North Carolina at Chapel

Hill, United States

Reviewed by:

Dirk De Beer,

Max Planck Society (MPG), Germany

Gordon T. Taylor,

Stony Brook University, United States

*Correspondence:

Shikma Zaarur

shikma.zaarur@mail.huji.ac.il

David T. Wang

dtw@alum.mit.edu

${ }^{\dagger}$ Present Address: Shikma Zaarur,

Institute of Earth Sciences, The

Hebrew University of Jerusalem, Jerusalem, Israel

${ }^{*}$ These authors have contributed equally to this work

Specialty section: This article was submitted to Microbiological Chemistry and

Geomicrobiology,

a section of the journal

Frontiers in Microbiology

Received: 14 February 2017 Accepted: 02 May 2017

Published: 29 May 2017

Citation:

Zaarur S, Wang DT, Ono S and

Bosak T (2017) Influence of Phosphorus and Cell Geometry on the

Fractionation of Sulfur Isotopes by

Several Species of Desulfovibrio during Microbial Sulfate Reduction.

Front. Microbiol. 8:890.

doi: 10.3389/fmicb.2017.00890

\author{
Shikma Zaarur ${ }^{\star \neq}$, David T. Wang ${ }^{*}$, Shuhei Ono and Tanja Bosak \\ Department of Earth, Atmospheric and Planetary Sciences, Massachusetts Institute of Technology, Cambridge, MA, United \\ States
}

We investigated the influence of organic substrates and phosphate concentration on the rates of dissimilatory microbial sulfate reduction and the ${ }^{34} \mathrm{~S} /{ }^{32} \mathrm{~S}$ isotopic fractionation produced by several Desulfovibrio species. Our experiments corroborate the previously reported species-specific correlation between sulfur isotope fractionation and cell-specific sulfate reduction rates. We also identify cell size as a key factor that contributes to the species-effect of this correlation. Phosphate limitation results in larger cells and contributes to a small decrease in sulfur isotope fractionation concomitant with an apparent increase in cell-specific sulfate reduction rates. Sulfur isotope fractionation in phosphate-limited cultures asymptotically approaches a lower limit of approximately

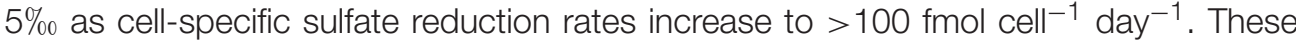
experimental results test models that link the reversibilities of enzymatic steps in dissimilatory sulfate reduction to sulfur isotope fractionation and show that these models can provide consistent predictions across large variations in physiological states experienced by sulfate reducing bacteria.

Keywords: sulfate reducing bacteria, organic substrate, phosphate limitation, sulfur isotopes, sulfur cycle

\section{INTRODUCTION}

The oxidation of organic matter by sulfate reducing bacteria (SRB) is a globally distributed anaerobic process that influences the redox state of the Earth's surface and the preservation of organic matter in sediments (Jørgensen, 1982; Westrich and Berner, 1984; Widdel and Hansen, 1992; Shen and Buick, 2004). Microbial sulfate reduction (MSR) fractionates sulfur isotopes, producing sulfide depleted in heavier isotopes. The magnitude of this fractionation $\left({ }^{34} \varepsilon\right.$, defined in Equation 6) is a critical parameter for reconstructions of the carbon and sulfur cycles through Earth history (Holland, 1973; Garrels and Lerman, 1981; Berner, 2001; Luo et al., 2016). For over half a century, many investigators have attempted to understand factors that affect sulfur isotope fractionation during MSR. Dozens of studies have reported fractionations produced in pure cultures of sulfate reducing organisms under controlled laboratory conditions (e.g., Harrison and Thode, 1958; Thode et al., 1961; Kaplan and Rittenberg, 1964; Chambers et al., 1975; Chambers and Trudinger, 1979), in experiments with natural microbial populations (e.g., Canfield, 2001; Canfield et al., 2010) and under in situ conditions (e.g., Jorgensen, 1979; Rudnicki et al., 2001; Wortmann et al., 2001). 
Marine sulfides exhibit a wide range of sulfur isotope compositions, ranging up to a $70 \%$ depletion in the ${ }^{34} \mathrm{~S} /{ }^{32} \mathrm{~S}$ ratio relative to that of the sulfate from which they were formed (Thode et al., 1953; Kaplan et al., 1963; Canfield and Teske, 1996). Because early laboratory studies could not reproduce fractionations of this magnitude in pure culture, they established a limit of $47 \%$ for single-step microbially mediated sulfate reduction (Kaplan and Rittenberg, 1964). Thus, for many decades, large fractionations $(>47 \%$ ) between sulfate and sulfide in rocks and natural environments were interpreted as evidence for oxidative recycling of sulfides or microbial disproportionation of intermediate sulfur species (e.g., Canfield and Thamdrup, 1994; Habicht and Canfield, 2001; Johnston et al., 2005). Recently, one bacterium (Desulfovibrio sp. DMSS-1), has been shown to produce fractionations that exceeded the $47 \% 0$ limit (Sim et al., 2011a). The largest fractionations (up to 66\%0) are produced during slow growth with glucose as the electron donor. This approaches the theoretical limit of $70 \%$ proposed for microbial sulfate reduction by Brunner and Bernasconi (2005).

In pure cultures, factors reported to influence the isotopic fractionation include temperature (Canfield et al., 2006), sulfate concentration (Canfield et al., 2000; Habicht et al., 2002; Bradley et al., 2015), availability and chemical properties of the electron donor (Harrison and Thode, 1958; Kaplan and Rittenberg, 1964; Chambers et al., 1975; Kleikemper et al., 2004; Sim et al., 2011a,b; Leavitt et al., 2013; Bradley et al., 2015; Antler et al., 2017), nutrient limitation (Sim et al., 2012), sulfate reduction rate (e.g., Harrison and Thode, 1958), altered gene expression (Sim et al., 2013; Leavitt et al., 2016), and unspecified strainspecific effects (Brüchert et al., 2001; Detmers et al., 2001). These factors can be mutually dependent. For example, when the type and concentration of electron donor (hydrogen or organic carbon compounds) dictate the cell-specific sulfate reduction rate (csSRR; per-cell respiration rate) in pure culture experiments, ${ }^{34} \varepsilon$ appears to be inversely proportional to csSRR (Chambers et al., 1975; Kleikemper et al., 2004; Hoek et al., 2006; Sim et al., 2011b; Leavitt et al., 2013). However, changes in bacterial species (Detmers et al., 2001) or growth temperature (Kaplan and Rittenberg, 1964; Canfield et al., 2006; Johnston et al., 2007) disrupt the correlation between ${ }^{34} \varepsilon$ and csSRR. This led Detmers et al. (2001) to hypothesize that growth on different electron donors would result in distinct ${ }^{34} \varepsilon$ vs. csSRR correlations for each species.

Here, we test this hypothesis by measuring sulfur isotope fractionations produced during dissimilatory sulfate reduction by several Desulfovibrio species (D. fructosovorans, D. inopinatus, and DMSS-1) grown in batch cultures on various substrates. We also examine the effect of phosphate limitation on sulfur isotope fractionation by SRB. Phosphate is an essential nutrient and a component of DNA, RNA, lipid membranes, and the energy carrier ATP that is used to activate sulfate during MSR (Peck, 1960; Cypionka, 1995; Muyzer and Stams, 2008). Its concentrations in oceanic and sedimentary environments may limit the growth of sulfate reducing bacteria in some natural environments (Bosak et al., 2016) and may have varied dramatically through Earth's history (Planavsky et al., 2010). Therefore, limitation by this essential nutrient may directly influence both the rates of sulfate reduction and the observed sulfur isotope fractionation.

Our results confirm a strong dependence of ${ }^{34} \varepsilon$ on organic substrates. The data are generally consistent with an inverse correlation between ${ }^{34} \varepsilon$ and csSRR. Offsets and deviations among SRB species appear to be rooted in morphological and physiological differences. Further offsets from the general inverse correlation may arise from intracellular responses to phosphorus starvation (Bosak et al., 2016). Comparisons of our data with predictions from recent efforts to numerically simulate isotopic signals produced via dissimilatory sulfate reduction (Wing and Halevy, 2014) test the predictions of these models over a range of conditions that sulfate reducing bacteria can experience in nature.

\section{METHODS}

\section{Cultures}

Three SRB species were used in this study: Desulfovibrio inopinatus, Desulfovibrio fructosovorans, and Desulfovibrio sp. DMSS-1. As is common in studies of isotope fractionation by $\mathrm{SRB}$, experiments were conducted in batch cultures. Isotope fractionation trends that were first identified from batch cultures have been confirmed by chemostat experiments in which steadystate conditions can be maintained (Sim et al., 2011a,b; Antler et al., 2017). Therefore, we consider batch cultures suitable for this study. Experimental cultures were grown on different substrates (lactate, fructose, malate, and/or pyruvate) and/or in media with different initial phosphate concentrations (from $<1 \mu \mathrm{M}$ to $>1 \mathrm{mM}$ ) and with excess sulfate as described below.

\section{Desulfovibrio inopinatus}

Desulfovibrio inopinatus (cat. no. 10711) was obtained from the German Collection of Microorganisms and Cell Cultures (DSMZ, Braunschweig, Germany: Catalogue of strains 1993). This microbe was isolated from marine sediments of Venice, Italy (Reichenbecher and Schink, 1997). Cultures were maintained anaerobically in glass serum bottles capped with butyl rubber septa under an atmosphere containing $80 \% \mathrm{~N}_{2}$ and $20 \% \mathrm{CO}_{2}$. Culture medium was prepared according to DSMZ recipe \#196-13871, with the exception of $\mathrm{NaCl}$ concentration because D. inopinatus grew better at $21 \mathrm{~g} / \mathrm{L}$ than at the $7 \mathrm{~g} / \mathrm{L}$ concentration suggested in the DSMZ recipe. The medium contains (per liter): $\mathrm{NaHCO}_{3}, 9.0$ g; $\mathrm{Na}_{2} \mathrm{SO}_{4}, 3.0$ g; $\mathrm{KH}_{2} \mathrm{PO}_{4}, 0.20$ g; $\mathrm{NH}_{4} \mathrm{Cl}$, 0.30 g; NaCl, $21 \mathrm{~g} ; \mathrm{KCl}, 0.50 \mathrm{~g}, \mathrm{MgCl}_{2} \cdot 6 \mathrm{H}_{2} \mathrm{O}, 3.1 \mathrm{~g} ; \mathrm{CaCl}_{2} \cdot 2 \mathrm{H}_{2} \mathrm{O}$, $0.15 \mathrm{~g}$; resazurin, $1 \mathrm{mg}$; a trace element solution (SL-10), $1 \mathrm{ml}$ (Widdel and Pfennig, 1981; Imhoff-Stuckle and Pfennig, 1983), and a general vitamin mix (described in DSMZ recipe \#141), $10 \mathrm{ml}$. Sodium ascorbate $(1.5 \mathrm{~g} / \mathrm{L})$ was added to maintain anoxic conditions (Kligler and Guggenheim, 1938). The medium did not contain any yeast extract. The $\mathrm{pH}$ of the medium was adjusted to 7.5 by dropwise addition of $1 \mathrm{M} \mathrm{NaOH}$ or $1 \mathrm{M} \mathrm{HCl}$ prior to inoculation.

Culture medium was supplemented with lactate $(28 \mathrm{mM})$, malate $(28 \mathrm{mM})$, or fructose $(14 \mathrm{mM})$ as organic substrate and sole electron donor. Initial concentrations of organic substrates were chosen such that sulfate would be in excess: sulfate 
reduction with stoichiometric conversion of any substrate to acetate would produce only $\sim 14 \mathrm{mM}$ of sulfide from the initial $21 \mathrm{mM}$ sulfate, see Table 1. For each experiment, 7-15 bottles were inoculated with $5 \%(\mathrm{v} / \mathrm{v})$ of a mid- to late-exponential phase pre-culture grown on the same organic substrate as that used in the experiment. Inoculums were pelleted via centrifugation and rinsed three times with clean medium in an anaerobic chamber (under an atmosphere of $80 \% \mathrm{~N}_{2}, 15 \% \mathrm{CO}_{2}$, and $5 \% \mathrm{H}_{2}$ ) to ensure the removal of all residual sulfide and organic substrate, and then transferred into $40 \mathrm{~mL}$ of fresh media. Bottles were incubated in the dark at room temperature. Microbial growth was monitored daily in one "master" bottle to minimize puncturing of septa of the experimental bottles. At each time point (Tables 2, 3), one experimental bottle was subsampled for cell counts and the colorimetric assay of sulfide concentration. The remaining culture volume was sacrificed by the addition of a $1 \mathrm{M}$ zinc acetate solution (at a $10 \% \mathrm{v} / \mathrm{v}$ ratio) to terminate microbial activity and precipitate sulfide as $\mathrm{ZnS}$ for isotopic analyses.

To test the effect of phosphate limitation, additional batch cultures were grown with varying initial concentrations of phosphate in the medium. Serum bottles used for these cultures were autoclaved three times with deionized water $(18.2 \mathrm{M} \Omega \cdot \mathrm{cm}$, Barnstead Nanopure ${ }^{\mathrm{TM}}$ filtration system) to remove residual phosphate. Medium was prepared as described above, with lactate $(28 \mathrm{mM})$ as organic substrate and without added phosphate. Phosphate (as $\mathrm{KH}_{2} \mathrm{PO}_{4}$ ) was then added from a concentrated stock solution, to final concentrations of 150, 15, and $3 \mu \mathrm{M}$. Another set of serum bottles did not receive any added phosphate. The concentration of phosphate in this nominally "0" phosphate medium was estimated to be $<1 \mu \mathrm{M}$ based on lot analyses provided with the chemicals used in the media (see also Experiments with Different Phosphate Concentrations). Figure A2 shows that $\sim 3$ to $5 \mu \mathrm{M}$ of added phosphate is limiting, suggesting that the blank is likely $<5 \mu \mathrm{M}$. Conclusions reached in this paper would be unaffected by a blank of $5 \mu \mathrm{M}$ or less. Experimental bottles (containing $10 \mathrm{~mL}$ of fresh media) were inoculated with a $5 \%(\mathrm{v} / \mathrm{v})$ sample of pre-cultures that were already conditioned to growth in the presence of lower or limiting concentrations of phosphate. Cell densities were low when phosphate was limiting, so inoculums were pelleted and rinsed only once to minimize the loss of biomass prior to inoculation. Cultures were monitored and sampled as described above.

\section{Desulfovibrio fructosovorans}

Desulfovibrio fructosovorans strain JJ (cat. no. 3604) was obtained from DSMZ. This strain was isolated from estuarine sediment (Jones et al., 1984; Cord-Ruwisch et al., 1986), and it incompletely oxidizes pyruvate, lactate, or fructose to acetate (Ollivier et al., 1988). The mineral medium (modified from DSMZ recipe \#63) contained (per liter): $\mathrm{NaHCO}_{3}, 2.6 \mathrm{~g} ; \mathrm{Na}_{2} \mathrm{SO}_{4}, 3.0 \mathrm{~g} ; \mathrm{KH}_{2} \mathrm{PO}_{4}$, $0.30 \mathrm{~g} ; \mathrm{NH}_{4} \mathrm{Cl}, 0.50 \mathrm{~g} ; \mathrm{KCl}, 0.20 \mathrm{~g} ; \mathrm{CaCl}_{2}, 0.10 \mathrm{~g} ; \mathrm{MgCl}_{2}, 2.0 \mathrm{~g}$; resazurin, $1 \mathrm{mg}$; SL-10 trace element solution (see above), $1 \mathrm{ml}$; vitamin solution \#141 (see above), $10 \mathrm{ml}$; and sodium ascorbate, $1.5 \mathrm{~g}$ (see above). Media were supplemented with limiting concentrations of one of the following organic substrates: lactate, $20 \mathrm{mM}$; pyruvate, $40 \mathrm{mM}$; or fructose, $10 \mathrm{mM}$. The starting concentrations of lactate, fructose, and pyruvate were chosen such that $10 \mathrm{mM}$ of sulfide would be produced by stoichiometric conversion of the substrate to acetate (Table 1). The $\mathrm{pH}$ of the medium was adjusted to 7.0 before inoculation. Bottles for all experiments with D. fructosovorans were inoculated with $5 \%$ $(\mathrm{v} / \mathrm{v})$ of a late-exponential phase pre-culture grown on lactate. Media and cultures were otherwise prepared and maintained as described for Desulfovibrio inopinatus above.

\section{Desulfovibrio sp. strain DMSS-1}

Desulfovibrio sp. DMSS-1 (henceforth “DMSS-1"), isolated from a salt marsh on Cape Cod, Massachusetts, USA and characterized by Sim et al. (2011b), was grown in batch cultures in the presence of varying concentrations of phosphate. Serum bottles were cleaned and prepared in the same manner as described above for D. inopinatus. Medium for DMSS-1 was prepared following Sim et al. (2011b), with the exception of phosphate, and contained (per liter): $\mathrm{NaHCO}_{3}, 9 \mathrm{~g} ; \mathrm{Na}_{2} \mathrm{SO}_{4}, 3 \mathrm{~g} ; \mathrm{NH}_{4} \mathrm{Cl}, 0.3 \mathrm{~g} ; \mathrm{NaCl}, 21 \mathrm{~g}$; $\mathrm{KCl}, 0.5 \mathrm{~g} ; \mathrm{MgCl}_{2} \cdot 6 \mathrm{H}_{2} \mathrm{O}, 6 \mathrm{~g} ; \mathrm{CaCl}_{2} \cdot 2 \mathrm{H}_{2} \mathrm{O} 0.3 \mathrm{~g}$; resazurin, $1 \mathrm{mg}$; SL-10 trace element solution (see above), $1 \mathrm{ml}$; vitamin solution \#141 (see above), $10 \mathrm{ml} ; 1 \mathrm{ml}$ of selenium stock solution $(0.4 \mathrm{mg}$ of $\mathrm{Na}_{2} \mathrm{SeO}_{3}$ per $200 \mathrm{ml}$ of $0.01 \mathrm{~N} \mathrm{NaOH}$ ); and sodium ascorbate,

TABLE 1 | Reaction stoichiometry of and Gibbs free energy change of reaction at biochemical standard state $\left(\Delta_{\mathrm{r}} G^{\circ}\right)$ and at $f=0.90\left(\Delta_{\mathrm{r}} G^{\prime} 0.90\right)$ for dissimilatory sulfate reduction via incomplete oxidation of lactate, malate, pyruvate, or fructose to acetate.

\begin{tabular}{|c|c|c|c|}
\hline Substrate & Reaction & $\Delta_{\mathrm{r}} \mathrm{G}^{\circ \prime}\left(\mathrm{kJ} \mathrm{\textrm {mol } ^ { - 1 }}\right)^{\mathrm{a}}$ & $\Delta_{\mathrm{r}} \mathrm{G}^{\prime}{ }_{0.90}\left(\mathrm{~kJ} \mathrm{~mol}^{-1}\right)^{\mathrm{b}}$ \\
\hline Lactate & $2 \mathrm{CH}_{3} \mathrm{CH}(\mathrm{OH}) \mathrm{COO}^{-}+\mathrm{SO}_{4}^{2-} \rightleftharpoons 2 \mathrm{CH}_{3} \mathrm{COO}^{-}+2 \mathrm{HCO}_{3}^{-}+\mathrm{HS}^{-}+\mathrm{H}^{+}$ & -170.7 & -193.5 \\
\hline Malate & $2 \mathrm{CO}\left(\mathrm{O}^{-}\right) \mathrm{CH}_{2} \mathrm{CH}(\mathrm{OH}) \mathrm{COO}^{-}+\mathrm{SO}_{4}^{2-} \rightleftharpoons 2 \mathrm{CH}_{3} \mathrm{COO}^{-}+4 \mathrm{HCO}_{3}^{-}+\mathrm{HS}^{-}+\mathrm{H}^{+}$ & -209.3 & -242.5 \\
\hline Pyruvate & $4 \mathrm{CH}_{3} \mathrm{COCOO}^{-}+\mathrm{SO}_{4}^{2-} \rightleftharpoons 4 \mathrm{CH}_{3} \mathrm{COO}^{-}+4 \mathrm{HCO}_{3}^{-}+\mathrm{HS}^{-}+3 \mathrm{H}^{+}$ & -340.1 & -379.8 \\
\hline Fructose & $\mathrm{C}_{6} \mathrm{H}_{12} \mathrm{O}_{6}+\mathrm{SO}_{4}^{2-} \rightleftharpoons 2 \mathrm{CH}_{3} \mathrm{COO}^{-}+2 \mathrm{HCO}_{3}^{-}+\mathrm{HS}^{-}+3 \mathrm{H}^{+}$ & -360.4 & -391.7 \\
\hline
\end{tabular}

Reaction stoichiometry from Cord-Ruwisch et al. (1986), Thauer et al. (1977), and Sim et al. (2011b). Values of $\Delta_{r} G^{\circ}$ ' are given at $298 \mathrm{~K}$ and 1 bar for a hypothetical ideal-dilute solution

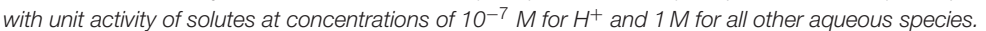

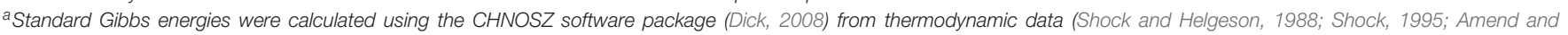
Plyasunov, 2001; Wagner and PruB, 2002; Dalla-Betta and Schulte, 2009) compiled in database updates to the SUPCRT92 program developed by Johnson et al. (1992).

${ }^{b}$ Gibbs energies of reaction were calculated at $25^{\circ} \mathrm{C}$ for medium compositions resembling those used for D. fructosovorans (see Methods), assuming $10 \%$ conversion of initial SO ${ }_{4}^{2-}$

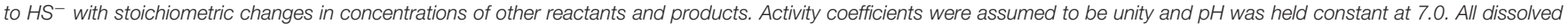
inorganic carbon was assumed to be as $\mathrm{HCO}_{3}^{-}$, and all sulfide as $\mathrm{HS}^{-}$. 
TABLE 2 | Physiological and isotopic data for batch cultures of $D$. fructosovorans and $D$. inopinatus grown on various substrates under non-phosphate-limited conditions.

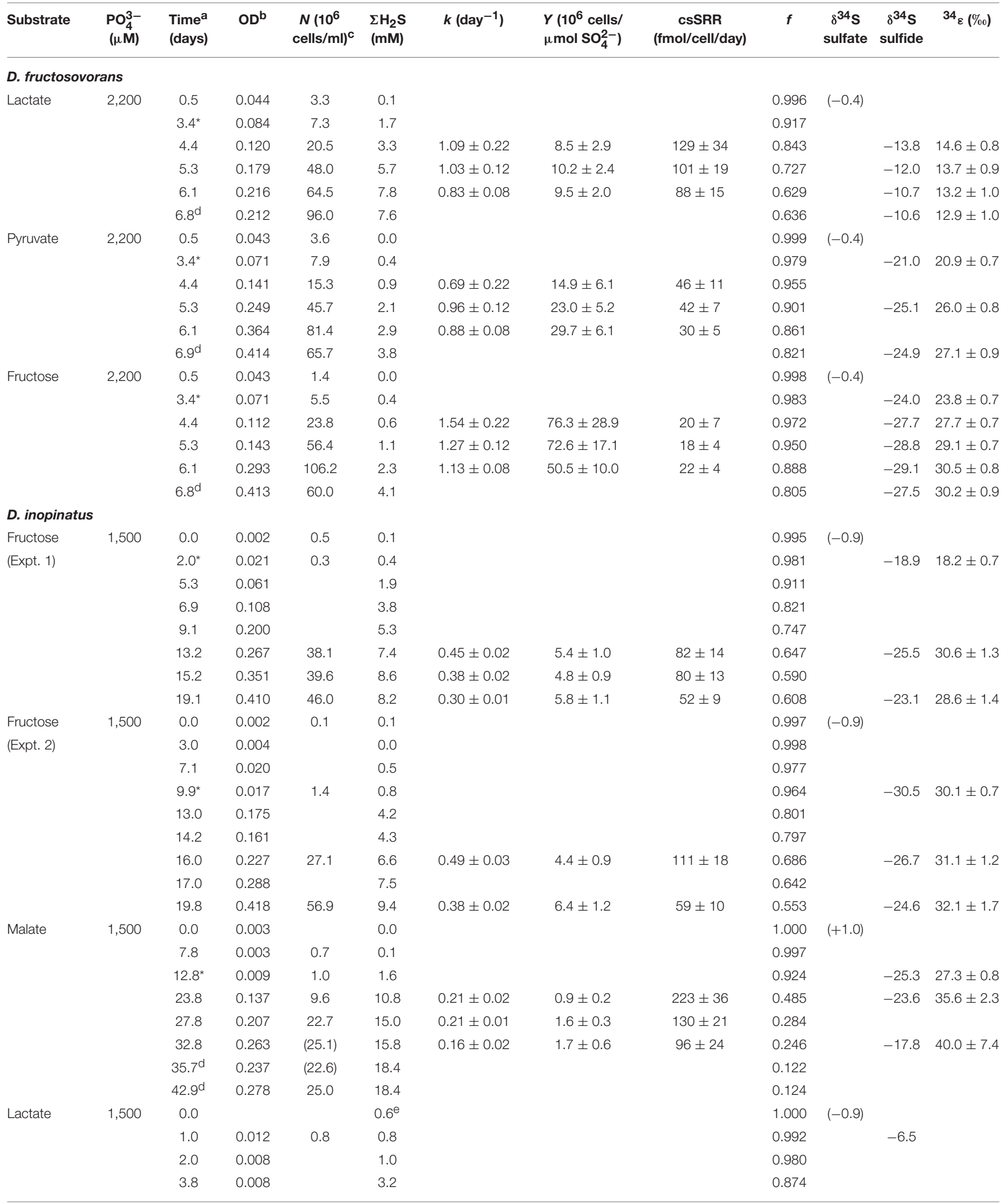


TABLE 2 | Continued

\begin{tabular}{|c|c|c|c|c|c|c|c|c|c|c|c|c|}
\hline Substrate & $\begin{array}{c}\mathrm{PO}_{4}^{3-} \\
(\mu \mathrm{M})\end{array}$ & $\begin{array}{c}\text { Time } \\
\text { (days) }\end{array}$ & $O D^{b}$ & $\begin{array}{l}N\left(10^{6}\right. \\
\text { cells/ml) }\end{array}$ & $\begin{array}{l}\Sigma H_{2} S \\
(m M)\end{array}$ & $k\left(\right.$ day $\left.^{-1}\right)$ & $\begin{array}{l}Y\left(10^{6} \text { cells/ }\right. \\
\left.\mu \mathrm{mol} \mathrm{SO}_{4}^{2-}\right)\end{array}$ & $\begin{array}{c}\text { csSRR } \\
\text { (fmol/cell/day) }\end{array}$ & $f$ & $\begin{array}{l}\delta^{34} S \\
\text { sulfate }\end{array}$ & $\begin{array}{l}\delta^{34} S \\
\text { sulfide }\end{array}$ & ${ }^{34} \varepsilon(\%)$ \\
\hline & & $4.9^{*}$ & 0.012 & 2.2 & 4.3 & & & & 0.823 & & -9.4 & $10.0 \pm 0.9$ \\
\hline & & 7.0 & 0.039 & (5.3) & 7.3 & $0.42 \pm 0.16$ & $1.3 \pm 0.8$ & $329 \pm 131$ & 0.679 & & & \\
\hline & & 7.9 & 0.085 & (15.4) & 8.8 & $0.64 \pm 0.11$ & $3.4 \pm 1.5$ & $191 \pm 62$ & 0.608 & & & \\
\hline & & 8.9 & 0.131 & 26.0 & 10.6 & $0.61 \pm 0.05$ & $4.2 \pm 1.1$ & $146 \pm 34$ & 0.525 & & -10.0 & $13.0 \pm 1.2$ \\
\hline & & 11.9 & 0.199 & $(40.0)$ & 9.7 & $0.42 \pm 0.05$ & $7.8 \pm 3.0$ & $53 \pm 17$ & 0.565 & & & \\
\hline & & 12.9 & 0.256 & 55.9 & 13.8 & $0.40 \pm 0.03$ & $6.0 \pm 1.4$ & $67 \pm 13$ & 0.371 & & -6.8 & $10.1 \pm 1.7$ \\
\hline & & $13.9^{d}$ & 0.248 & (50.5) & 13.1 & & & & 0.406 & & & \\
\hline
\end{tabular}

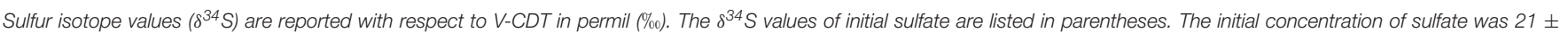

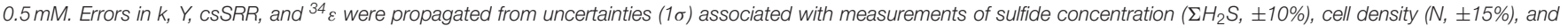
$\delta^{34} S( \pm 0.5 \%$ ) by standard methods (Ku, 1969).

a Time points marked with an asterisk $\left(^{*}\right)$ were taken to be the beginning of exponential growth ( $t_{1}$, see Calculations).

${ }^{b}$ Optical density measured at $630 \mathrm{~nm}$ for $D$. fructosovorans and $660 \mathrm{~nm}$ for $D$. inopinatus.

${ }^{c}$ Cell densities shown in parentheses are extrapolated from optical density data calibrated to microscopy-based cell counts.

${ }^{d}$ These time points represent cultures that have reached stationary phase, and as such, $k, Y$, and csSRR are not listed.

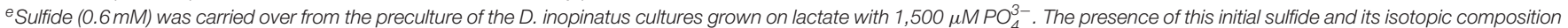
was accounted for in the calculation of $f$ and ${ }^{34} \varepsilon$ for this experiment.

$1.5 \mathrm{~g}$ (see above). Phosphate was added to final concentrations of $360,36,5 \mu \mathrm{M}$, and “0” (<1 $\mu \mathrm{M})$.

\section{Analyses \\ Cell Counts and Sulfide Assays}

Growth was monitored using optical density (OD) measurements and microscopic cell counts. OD was measured at 630 or $660 \mathrm{~nm}$ using a spectrophotometer (Synergy 2 microplate reader, BioTek, Winooski, Vermont, USA). For cell counts, subsamples of experimental cultures were preserved in $2.5 \%$ glutaraldehyde at $4^{\circ} \mathrm{C}$. Preserved cells were stained with SYBR Green I nucleic acid stain (Invitrogen Molecular Probes, Eugene, Oregon, USA), and filtered onto Whatman $0.2 \mu \mathrm{m}$ Nuclepore polycarbonate filters. Stained cells were visualized and imaged by epifluorescence microscopy using a Zeiss Axio Imager M1 microscope (Carl Zeiss Microscopy, LLC), and cell densities were determined by manual counting (Noble and Fuhrman, 1998). Cell lengths and widths were measured in the epifluorescence micrographs using measuring tools in Zeiss AxioVision software.

Sulfide from subsamples was precipitated as $\mathrm{ZnS}$ in a $50 \mathrm{mM}$ zinc acetate solution, and stored at $4^{\circ} \mathrm{C}$ until analysis. Sulfide concentrations $\left(\mathrm{\Sigma H}_{2} \mathrm{~S}=\mathrm{H}_{2} \mathrm{~S}+\mathrm{HS}^{-}+\mathrm{S}^{2-}\right)$ were determined by a modified methylene blue colorimetric method (Cline, 1969). Briefly, $200 \mu \mathrm{L}$ samples of medium were reacted with $1 \mathrm{ml}$ of $0.05 \mathrm{M}$ zinc acetate and $10 \mu \mathrm{L}$ of $N, N$-dimethyl- $p$ phenylenediamine sulfate solution. Optical density was read at $670 \mathrm{~nm}$ using a microplate reader (Sim et al., 2011b).

\section{Sulfur Isotope Ratios}

Sulfide was extracted for isotopic analysis by acidifying each $\mathrm{ZnS}$ sample with 3 to $6 \mathrm{M} \mathrm{HCl}$, and gently boiling for $1 \mathrm{~h}$ under a stream of $\mathrm{N}_{2}$ gas. Sulfate in samples were then converted to $\mathrm{H}_{2} \mathrm{~S}$ using a general reducing agent $\left(\mathrm{HCl}, \mathrm{HI}\right.$, and $\left.\mathrm{H}_{3} \mathrm{PO}_{2}\right)$ (Thode et al., 1961; Forrest and Newman, 1977; Arnold et al.,
2014). Volatiles were passed through a condenser and a distilled $\mathrm{H}_{2} \mathrm{O}$ trap. $\mathrm{H}_{2} \mathrm{~S}$ produced in the reactions was precipitated as $\mathrm{ZnS}$ in zinc acetate, and then converted to $\mathrm{Ag}_{2} \mathrm{~S}$ via addition of silver nitrate, or precipitated as $\mathrm{Ag}_{2} \mathrm{~S}$ directly in a silver nitrate solution. The recovered $\mathrm{Ag}_{2} \mathrm{~S}$ was washed with deionized water, dried at $70^{\circ} \mathrm{C}$, and converted to $\mathrm{SF}_{6}$ by reaction with $\mathrm{F}_{2}$ at $300^{\circ} \mathrm{C}$ overnight. The $\mathrm{SF}_{6}$ product was purified by cryogenic trapping and preparative gas chromatography, and analyzed on a ThermoFinnigan MAT 253 isotope-ratio mass spectrometer operated in dual-inlet mode as described previously (Ono et al., 2006).

Sulfur isotope values are reported in the standard $\delta$ notation against Vienna Cañon Diablo Troilite (VCDT):

$$
\delta^{34} S_{\text {sulfide }}=\frac{\left({ }^{34} \mathrm{~S} /{ }^{32} \mathrm{~S}\right)_{\text {sample }}}{\left({ }^{34} \mathrm{~S} /{ }^{32} \mathrm{~S}\right)_{\mathrm{VCDT}}}-1
$$

Following IUPAC recommendations (Coplen, 2011), we have omitted the factor of $1000 \%$ from the definition of $\delta$ in Equation 1.

\section{Calculations}

Specific growth rates $(k)$ for the cultures were calculated using an exponential growth equation (Monod, 1949):

$$
k_{x}=\frac{\ln \left(N_{x} / N_{1}\right)}{t_{x}-t_{1}}
$$

where $N_{x}$ and $N_{1}$ are the cell densities (number of cells per milliliter) at $t_{x}$ and $t_{1}$, respectively (Sim et al., 2011b). Growth rates calculated in this manner represent an average of the cumulative growth of the organism over the time interval between the beginning of exponential growth $\left(t_{1}\right)$ and the time at which the sample was taken $\left(t_{x}\right)$. 
Cellular growth yields $(Y)$ were calculated with respect to amount of produced sulfide: ${ }^{1}$

$$
Y_{x}=\frac{N_{x}-N_{1}}{\left[\mathrm{H}_{2} \mathrm{~S}\right]_{x}-\left[\mathrm{H}_{2} \mathrm{~S}\right]_{1}}
$$

The cell-specific sulfate reduction rate (csSRR) is defined as the amount of sulfate reduced per cell per unit time, and can be described as:

$$
\operatorname{csSRR}_{x}=k_{x} / Y_{x}
$$

In a batch culture, isotopic fractionation factors can be determined from a Rayleigh distillation equation for closed systems. Here, we use the measured isotopic composition of the produced sulfide $\left(\delta^{34} S_{\text {sulfide }}\right)$ to calculate the fractionation factor $\alpha$, assuming isotopic mass balance between sulfide and remaining sulfate:

$$
\alpha=(\ln f)^{-1} \times \ln \left[1-(1-f) \times \frac{\delta^{34} S_{\text {sulfide }}+1}{\delta^{34} S_{\text {initial }}+1}\right]
$$

where $\delta^{34} S_{\text {initial }}$ and $\delta^{34} S_{\text {sulfide }}$ are the measured isotopic compositions of the initial sulfate in the media and the produced sulfide respectively, and $f$ is the fraction of initial sulfate that remained at the time of sampling. The value of $f$ is calculated from measured $\Sigma_{2} \mathrm{H}_{2} \mathrm{~S}$ concentrations and assuming that all consumed sulfate was reduced into sulfide.

The isotopic enrichment factor $\left({ }^{34} \varepsilon\right)$ is defined as:

$$
{ }^{34} \varepsilon=1-{ }^{34} \alpha
$$

According to this definition, positive ${ }^{34} \varepsilon$ values represent depletion of ${ }^{34} \mathrm{~S}$ in sulfide with respect to sulfate.

${ }^{1}$ Cellular yield $(Y)$ has units of cells per mole sulfate. It is a measure of the number of cells supported by a given amount of transferred electrons. Relating $Y$ to biomass yield (i.e., $\mathrm{g} \mathrm{mol}^{-1}$ ) requires accounting for cell size differences.

\section{RESULTS}

\section{Experiments with Different SRB Species and Substrates}

Table 2 shows data from experiments that were designed to test the dependence of sulfur isotope fractionation on species (D. fructosovorans and D. inopinatus) and substrates (lactate, fructose, malate, or pyruvate). Batch cultures used in these experiments were typically grown to late exponential phase. Cultures of $D$. fructosovorans grew in media with fructose, pyruvate, or lactate as the organic substrate. Exponential growth was observed within 2 to 3 days, and experiments lasted for 7 days (Figure A1). Growth rates $(k)$ on all three substrates ranged between 0.6 and 1.5 day $^{-1}$. Cultures of $D$. inopinatus grew in media that contained fructose, malate or lactate as the electron donors. Growth experiments with $D$. inopinatus lasted 14, 20, and 43 days, respectively, for cultures grown on lactate, fructose and malate, respectively, due to the longer lag phase (Figure A1). Growth rates of D. inopinatus in cultures grown on fructose and lactate were similar $\left(0.40\right.$ and 0.44 day $^{-1}$, respectively), but were lower during growth on malate $(0.17$ day $\left.^{-1}\right)$. Sulfide concentrations in all cultures increased with the increasing cell densities (Figure A1). Cultures of $D$. inopinatus grown on malate produced more sulfide (up to $18 \mathrm{mM}$ ) than the $14 \mathrm{mM}$ concentration predicted by incomplete malate oxidation (Table 1), perhaps indicating that some of the malate may have been oxidized completely to $\mathrm{CO}_{2}$ or to small organic compounds.

$D$. inopinatus cells were both longer and wider than cells of D. fructosovorans and DMSS-1 (Figure 1). Cell morphology appeared to be mostly independent of organic substrate (Table 4), but small, measurable differences were observed in some cultures of $D$. inopinatus. Cells of $D$. inopinatus were on average $\sim 1 \mu \mathrm{m}$ longer when grown on malate compared to fructose or lactate, and slightly wider (by $\sim 0.3 \mu \mathrm{m}$ ) when grown on fructose compared to malate or lactate. Cells of D. fructosovorans grown on different substrates did not exhibit measurable differences.

Calculated sulfur isotope enrichment factors $\left({ }^{34} \varepsilon\right)$ ranged from 13 to $31 \%$ in D. fructosovorans cultures and from 10 to $40 \%$ in D. inopinatus cultures (Table 2). The smallest ${ }^{34} \varepsilon$ values
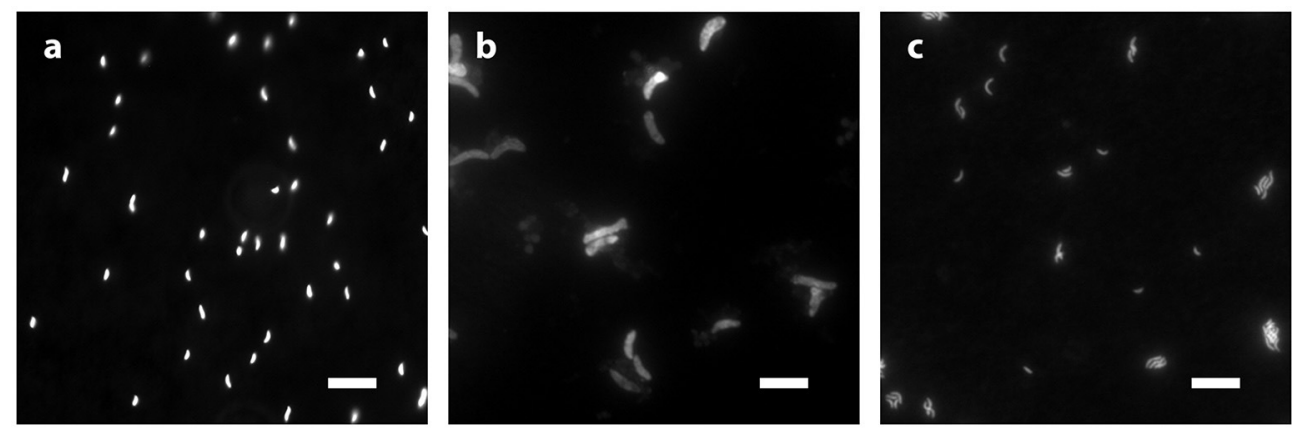

FIGURE 1 | Morphology of species growing in phosphate-rich media and visualized by epifluorescence microscopy: (a) $D$. fructosovorans (pyruvate, $2,200 \mu \mathrm{M} \mathrm{PO}_{4}^{3-}$, 6.1 days); (b) $D$. inopinatus (malate, 1,500 $\mu \mathrm{M} \mathrm{PO}_{4}^{3-}, 27.8$ days); and (c) DMSS-1 (lactate, $360 \mu \mathrm{M} \mathrm{PO}_{4}^{3-}$, 6.1 days). Scale bars in all panels represent $10 \mu \mathrm{m}$. 
(averaging 13 and $11 \%$ for the two species, respectively) were observed in cultures grown on lactate. When grown on fructose, both bacteria exhibited $15-17 \%$ larger ${ }^{34} \mathrm{~S} /{ }^{32} \mathrm{~S}$ fractionations. The highest enrichment factors, up to $40 \%$, were observed in the cultures of $D$. inopinatus grown on malate (Table 2).

\section{Experiments with Different Phosphate Concentrations}

Data shown in Table 3 are from experiments that test the effect of variable phosphate concentrations on D. inopinatus and DMSS-1. Cultures grown in media containing initial phosphate concentrations $\leq 15$ and $\leq 5 \mu \mathrm{M}$ for $D$. inopinatus and DMSS- 1 , respectively, had smaller growth rates and cell densities relative to cultures grown at higher phosphate levels $(\geq 150$ and $\geq 36 \mu \mathrm{M}$; Figure A2). At the lowest phosphate concentration (nominally $<1 \mu \mathrm{M}$ ), the optical density of $D$. inopinatus increased slowly, but that of DMSS-1 did not increase over a period of 43 days. Sulfide was produced under all tested conditions, though $D$. inopinatus and DMSS-1, produced only up to 2.3 and $0.3 \mathrm{mM}$ of sulfide, respectively, when no phosphate was added to the growth media (Figure 4). Growth rates and csSRR of D. inopinatus and DMSS-1 were the highest at 15 and $36 \mu \mathrm{M}$ phosphate, respectively.

Low phosphate concentrations strongly influenced the cell morphology (Table 4). At the lowest phosphate condition $(<1 \mu \mathrm{M})$, the average $D$. inopinatus cell was up to five times longer (Figure 2), whereas the average cell length of DMSS-1 increased up to three times relative to the phosphate-replete conditions. In addition, the variance $\left(\sigma^{2}\right)$ in cell length (Table 4) was larger at lower phosphate concentrations: cell sizes at high concentrations of phosphate were rather uniform, but both "normal" single cells with typical lengths $(\sim 7 \mu \mathrm{M})$ and extremely long chains (over $100 \mu \mathrm{m}$ in D. inopinatus cultures, Figure 2) were present at low phosphate concentrations. The cell lengths were strongly correlated with the phosphate concentration in the cultures of both organisms (Figure 3), and cell lengths typically increased with time in each phosphate-limited experiment. Samples were vigorously vortexed prior to staining, filtration, and visualization. Because these procedures did not separate these long chain-looking cells and no cell wall was recognized, we counted them as single cells. However, microscopy-based cell counts were challenging because a single long chain-like cell (as long as 10 individual cells) can appear similar to a chain of several cells of shorter length located end-to-end (e.g., Figure 2c). These issues may cause some of the scatter in the growth rate and csSRR data, but should not affect the overall trends observed in this study.

The isotopic composition of sulfide was measured during mid-exponential growth phase in most of our experiments, with the exception of the culture of DMSS-1 grown with $<1 \mu \mathrm{M}$ initial phosphate, where $\delta^{34} \mathrm{~S}_{\text {sulfide }}$ was measured at 42.8 days, and growth was not detected at any point during the experiment. While measured $\delta^{34} \mathrm{~S}_{\text {sulfide }}$ values varied little, from -5.8 to $-6.6 \%$ for D. inopinatus and from -3 to $-4.7 \%$ for DMSS-1, the calculated enrichment factors $\left({ }^{34} \varepsilon\right)$ decreased with decreasing phosphate concentrations (Figure 4a). The ${ }^{34} \varepsilon$ values in D. inopinatus cultures grown with lactate decreased from
$16 \%$ at $150 \mu \mathrm{M}$ phosphate (similar to regular, phosphate-replete conditions) to $7 \%$ at $<1 \mu \mathrm{M}$ phosphate. The ${ }^{34} \varepsilon$ values of DMSS- 1 cultures decreased from 8 to $5 \%$ over a similar range of phosphate concentrations.

\section{DISCUSSION}

\section{Variation of ${ }^{34} \varepsilon$ with Substrates and Species \\ Differences among Species}

Both $D$. fructosovorans and $D$. inopinatus discriminate against heavier isotopes of sulfur more when they grow on fructose $\left({ }^{34} \varepsilon \sim 30 \%\right.$ ) relative to the growth on lactate (10 to $15 \% 0$ ). Data from Sim et al. (2011b) for DMSS-1 growing on fructose (30 to $40 \%$ ) and lactate $(\sim 6 \%$ ) in batch cultures exhibited the same trend and similar ranges of ${ }^{34} \varepsilon$. Growth on pyruvate and malate yielded ${ }^{34} \varepsilon$ values that were dissimilar among the studied species. While fractionations during the growth on pyruvate were larger than those during the growth on lactate and smaller than those during the growth on fructose for both $D$. fructosovorans and DMSS-1, ${ }^{34} \varepsilon$ was $\sim 27 \%$ for the former species, but only $8 \%$ for the latter. The relatively high fractionation by pyruvate-grown $D$. fructosovorans contrasts with previous studies of sulfate reducing bacteria that oxidize organic substrates completely to $\mathrm{CO}_{2}$. These microbes generally produce values of ${ }^{34} \varepsilon$ smaller than $19 \%$ when oxidizing pyruvate to acetate in batch culture (Brüchert, 2004; Sim et al., 2011b). An increased fractionation may be a consequence of simultaneous fermentation and respiration of pyruvate, an effect that has been inferred in cultures of $D$. vulgaris Hildenborough and other species (Sass et al., 2002; Sim et al., 2013), and to which higher fractionations could be attributed (Sim et al., 2013). Another unexplained difference in fractionation is evident during the growth on malate by $D$. inopinatus (up to $\sim 40 \%$ ) and DMSS-1 (ca. 17\% ). Such differences suggest that the magnitude of sulfur isotope fractionations is not a direct function of the organic substrate itself, but depends on the specific pathways by which organisms take up and oxidize organic compounds, transfer the reducing equivalents to sulfate (or instead to an organic compound via fermentation), and generate ATP.

\section{${ }^{34} \varepsilon$ and csSRR}

The trend in ${ }^{34} \varepsilon$ vs. csSRR for $D$. fructosovorans generally resembles the inverse correlations reported by several previous studies (Harrison and Thode, 1958; Kaplan and Rittenberg, 1964; Chambers et al., 1975; Kleikemper et al., 2004; Hoek et al., 2006; Sim et al., 2011a,b; Leavitt et al., 2013). Data from several of these studies are shown in Figure 5a. D. inopinatus data fall within the range observed for other Desulfovibrio species, but there is no clear trend between ${ }^{34} \varepsilon$ and csSRR; this may be in part due to the high fractionations observed during growth on malate. In general, trends for different species are subparallel in ${ }^{34} \varepsilon-\log _{10}$ (cSSRR) space, have different slopes and intercepts, and may be offset by several orders of magnitude in csSRR. These observations are evidence of the complexity that depends on species-specific responses to substrates and growth conditions. 
TABLE 3 | Physiological and isotopic data for batch cultures of $D$. inopinatus and DMSS-1 grown on lactate in the presence of varying concentrations of phosphate $\left(\mathrm{PO}_{4}^{3-}\right)$.

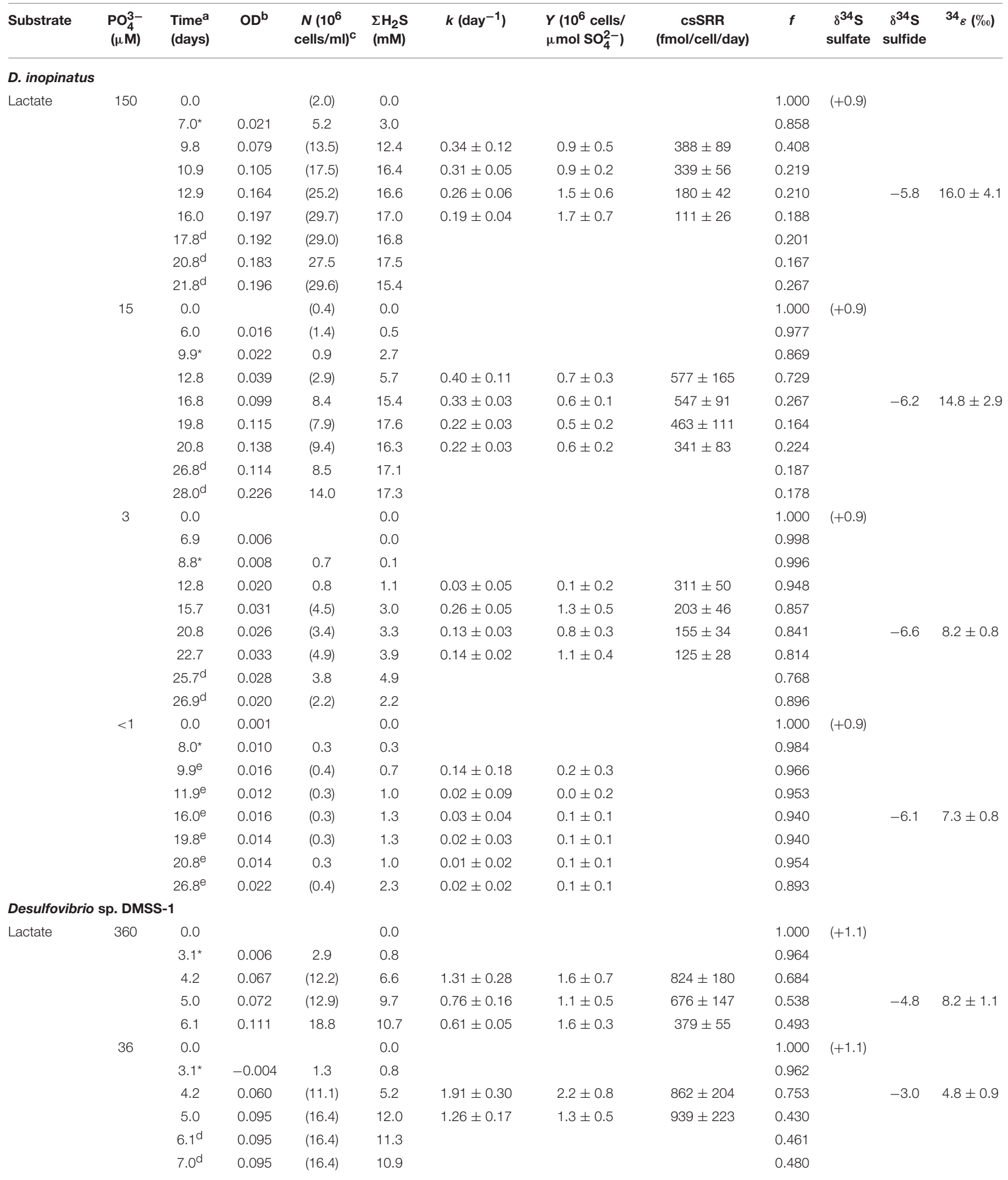


TABLE 3 | Continued

\begin{tabular}{|c|c|c|c|c|c|c|c|c|c|c|c|c|}
\hline Substrate & $\begin{array}{l}\mathrm{PO}_{4}^{3-} \\
(\mu \mathrm{M})\end{array}$ & $\begin{array}{l}\text { Time } \\
\text { (days) }\end{array}$ & $O D^{b}$ & $\begin{array}{l}N\left(10^{6}\right. \\
\text { cells/ml)c }\end{array}$ & $\begin{array}{l}\Sigma \mathrm{H}_{2} \mathrm{~S} \\
(\mathrm{mM})\end{array}$ & $k\left(\right.$ day $\left.^{-1}\right)$ & $\begin{array}{l}Y\left(10^{6} \text { cells/ }\right. \\
\left.\mu \mathrm{mol} \mathrm{SO}_{4}^{2-}\right)\end{array}$ & $\begin{array}{c}\text { csSRR } \\
\text { (fmol/cell/day) }\end{array}$ & $f$ & $\begin{array}{l}\delta^{34} S \\
\text { sulfate }\end{array}$ & $\begin{array}{l}\delta^{34} S \\
\text { sulfide }\end{array}$ & ${ }^{34} \varepsilon(\%)$ \\
\hline & \multirow[t]{4}{*}{5} & 0.0 & 0.001 & (2.2) & 0.0 & & & & 1.000 & $(+1.1)$ & & \\
\hline & & 6.0 & 0.016 & (4.5) & 2.2 & $0.21 \pm 0.20$ & $1.3 \pm 1.3$ & $165 \pm 47$ & 0.894 & & -3.9 & $5.3 \pm 0.8$ \\
\hline & & 13.0 & 0.038 & $(7.7)$ & 7.7 & $0.11 \pm 0.04$ & $0.7 \pm 0.4$ & $149 \pm 35$ & 0.631 & & & \\
\hline & & $14.9^{d}$ & 0.036 & (7.5) & 8.2 & & & & 0.612 & & & \\
\hline & \multirow[t]{5}{*}{$<1$} & 0.0 & & $(1.8)$ & 0.0 & & & & 1.000 & $(+1.1)$ & & \\
\hline & & 7.9 & 0.001 & (2.2) & 0.0 & & & & 1.000 & & & \\
\hline & & 13.0 & 0.000 & $(1.8)$ & & & & & & & & \\
\hline & & $14.8^{\star}$ & 0.000 & (2.1) & 0.0 & & & & 0.999 & & & \\
\hline & & $21.7^{e}$ & 0.000 & (1.6) & 0.0 & $-0.04 \pm 0.05$ & $227 \pm 7216$ & & 1.000 & & & \\
\hline
\end{tabular}

See caption of Table 2 for explanations of data columns.

a Time points marked with an asterisk $\left(^{*}\right)$ were taken to be the beginning of exponential growth ( $t_{1}$, see Calculations).

${ }^{b}$ Optical density measured at $660 \mathrm{~nm}$.

${ }^{c}$ Cell densities shown in parentheses are extrapolated from optical density data calibrated to microscopy-based cell counts.

${ }^{d}$ These time points represent cultures that have reached stationary phase, and as such, $k, Y$, and csSRR are not listed.

eNo growth and/or sulfide production was detected. Uncertainties in $k$ and/or Y exceed the values themselves; therefore, csSRRs calculated for these time points would be spurious and are not listed.
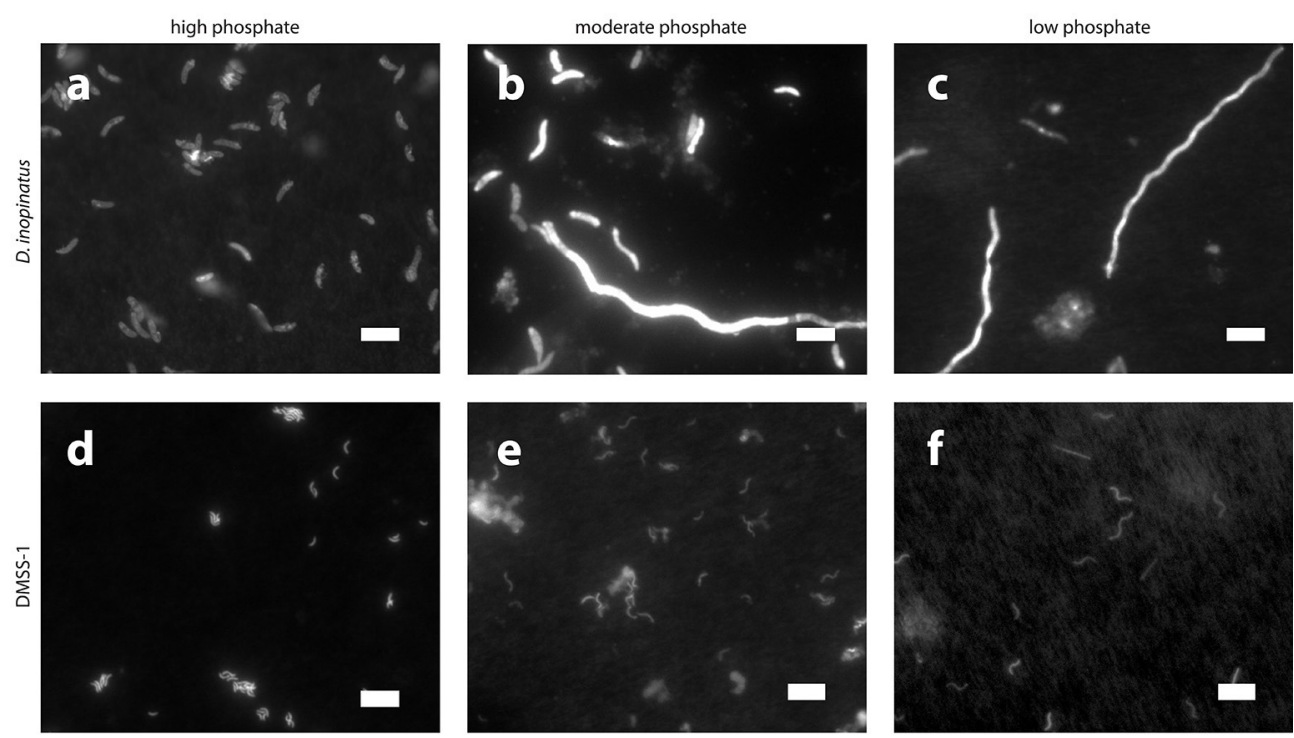

FIGURE 2 | Epifluorescence photomicrographs of cultures grown on lactate in the presence of different concentrations of phosphate. Top row,

D. inopinatus in (a) $1,500 \mu \mathrm{M} \mathrm{PO}_{4}^{3-}$ (12.9 days); (b) $15 \mu \mathrm{M}$ (14.7 days); and (c) $<1 \mu \mathrm{M}$ (8.0 days). Bottom row, DMSS-1 in (d) $360 \mu \mathrm{M} \mathrm{PO} 4-(6.1$ days, see also Figure 1c for inset); (e) $5 \mu \mathrm{M}$ (13.0 days); and (f) $<1 \mu \mathrm{M}$ (42.8 days). Scale bars represent $10 \mu \mathrm{m}$. Panels (b,c,f) show long chain-like single cells.

\section{Cell Size and ${ }^{34} \varepsilon$}

The three Desulfovibrio species have very different cell sizes despite their grossly similar vibrioid morphology (Figure 1), and generally, higher sulfate reduction rates are observed in the larger cells. To test whether the surface areas or volumes of cells account for some of the observed differences in CSSRR between species, we expressed ${ }^{34} \varepsilon-\log _{10}$ (sulfate reduction rate) relationships per unit of cell surface area or volume. To estimate the surface areas and volumes, we measured the cell dimensions of $D$. inopinatus, $D$. fructosovorans and DMSS-1 grown in this study and those of $\mathrm{DvH}$ previously grown in our laboratory (Sim et al., 2013; Table 4). The csSRR values were divided by either surface area or volume, and expressed as "cell area (or volume) normalized sulfate reduction rate" [canSRR or cvnSRR; 
TABLE 4 | Cell sizes (values are mean $\pm 1 \sigma$ measured on $n>30$ cells).

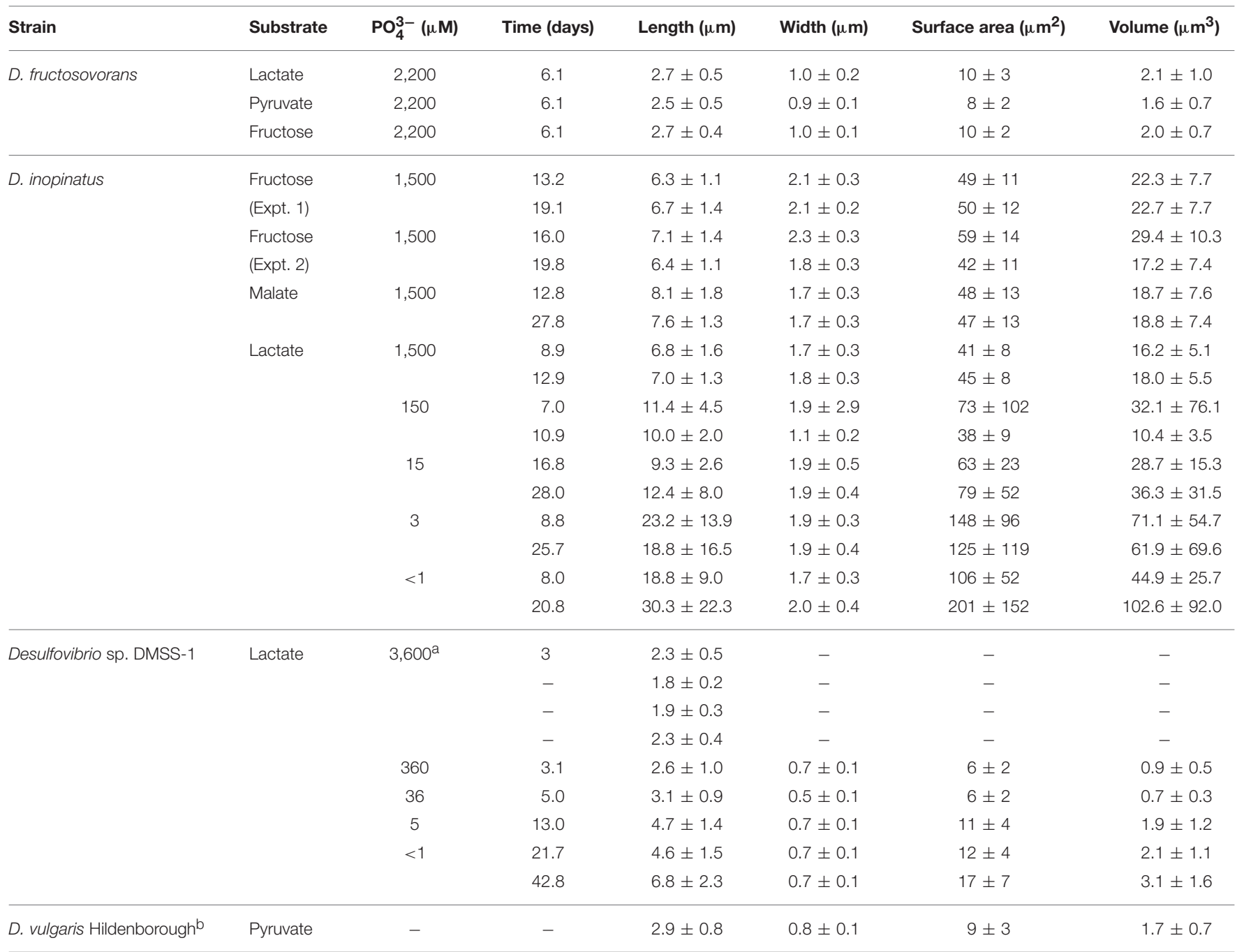

Surface areas and volumes were calculated for individual cells by approximating each cell as a cylinder.

a Data from Sim et al. (2011b) for batch and continuous cultures of DMSS-1.

${ }^{b}$ Data from microscopy images taken by Sim et al. (2013) of a continuous culture of D. vulgaris Hildenborough.

units of fmol $\mathrm{H}_{2} \mathrm{~S}(\mu \mathrm{m})^{-2}$ day $^{-1}$ or fmol $\mathrm{H}_{2} \mathrm{~S}(\mu \mathrm{m})^{-3}$ day $^{-1}$, respectively]. Figures $\mathbf{5 b}, \mathbf{c}$ show the ${ }^{34} \varepsilon$ data for these species plotted against sulfate reduction rates normalized in this manner. Non-linear least-squares regression of a modified MichaelisMenten-type equation (see Figure 5 legend) to plots of ${ }^{34} \varepsilon$ against canSRR or cvnSRR has higher coefficients of determination $\left(R^{2}\right)$ of 0.55 or 0.56 (respectively), compared to 0.43 for ${ }^{34} \varepsilon$ against csSRR. Thus, normalizing sulfate reduction rates to either cell surface area or cell volume reduces the scatter of the data (Figure 5). The improved fits may arise from the distribution of membrane transport proteins across the cell surface, and from the constraints on the amounts of enzyme in a single cell by the cell volume (Pomeroy et al., 2007). This result underscores similarities in the isotopic signals produced per unit of membrane area or biomass of different cultured sulfate reducing microbes, in spite of their differing cell geometries, growth rates, and capacities to oxidize different electron donors. We hypothesize that the larger cells require more energy (electrons) per cell to synthesize cellular components, and therefore exhibit higher csSRR values. Normalizing the sulfate reduction rate to cell volume eliminates that inherent difference amongst microbial species. Alternatively or additionally, larger cells also have larger surface areas that allow larger fluxes of sulfate in to the cell through the cell membrane.

We recognize that cell sizes almost certainly cannot explain all of the variation between the subparallel ${ }^{34} \varepsilon-\log _{10}$ (csSRR) trends, and other factors such as the capacity for complete oxidation of organic substrates, growth temperature, and efficiency of sulfate transport may be important (Detmers et al., 2001; Canfield et al., 2006; Bradley et al., 2015). However, similarities amongst the normalized data for several Desulfovibrio species strongly indicate that biomass and cell sizes influence the observed ${ }^{34} \varepsilon$ in experimental and environmental studies. Ideally, we would compare our results to more of the previously published ${ }^{34} \varepsilon$ 


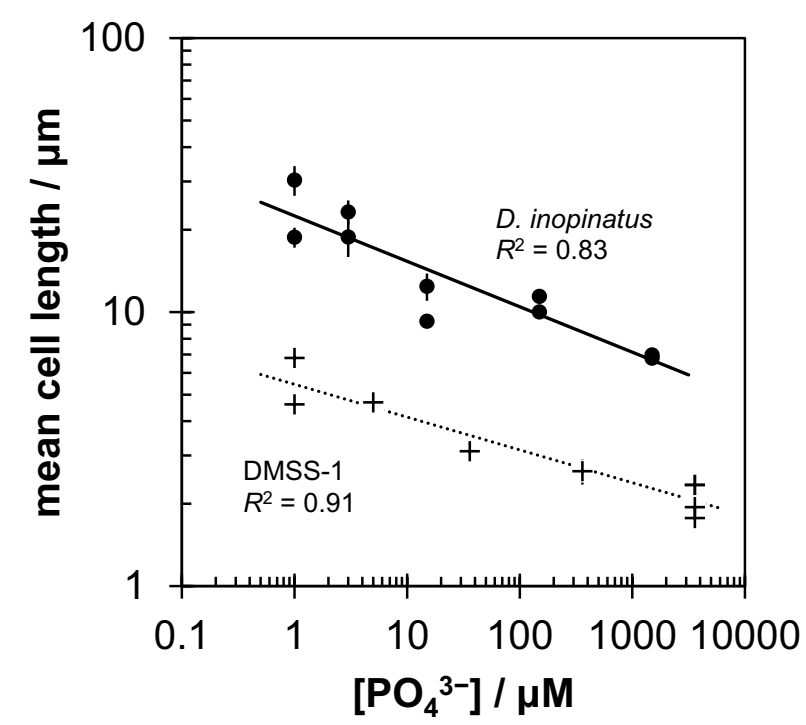

FIGURE 3 | Relationship between mean cell length and initial phosphate concentration in cultures of $D$. inopinatus $(\bullet)$ and DMSS-1 (+) grown on lactate. Data are from Table 4. Vertical error bars are 1 s.e.m. (standard error of the mean). For DMSS-1, error bars are smaller than the symbols.

values reported for SRB and archaea. However, neither the original descriptions of the SRBs, nor previous isotopic studies of MSR provide detailed cell size measurements that are required for this type of analysis. Rather, they report cell size ranges and do not examine the dependence of the cell size on the growth condition. The broad variations in these ranges translate into a large range of cell volumes and do not allow meaningful comparisons with our data. We encourage future studies of MSR in pure cultures to report cell sizes or biomass as functions of growth condition.

\section{Fractionation of Sulfur Isotopes under Phosphorus Limitation Morphological and Physiological Effects}

Both D. inopinatus and DMSS-1 had slower growth rates $(k)$ when limited by phosphate (Figure $\mathbf{4 b}$ and Table 3 ). The growth rate data for D. inopinatus are in good agreement with the Monod equation (Equation 7) (Monod, 1949) for a half-saturation constant $\left(K_{\mathrm{M}}\right)$ of $\sim 10 \mu \mathrm{M}$ phosphate (Figure $4 \mathbf{b}$ ). Growth rates for DMSS-1 are more scattered but also decrease below $\sim 10 \mu \mathrm{M}$ phosphate.

$$
k=k_{\max } \frac{\left[\mathrm{PO}_{4}^{3-}\right]}{K_{\mathrm{M}}+\left[\mathrm{PO}_{4}^{3-}\right]}
$$

Phosphate limitation at $\sim 10 \mu \mathrm{M}$ for these species is similar to observations of phosphate limited growth at $<12 \mu \mathrm{M}$ for D. desulfuricans (Okabe and Characklis, 1992) and $\sim 10 \mu \mathrm{M}$ for D. alaskensis G20 (Bosak et al., 2016), suggesting that many Desulfovibrio species may use similar mechanisms to

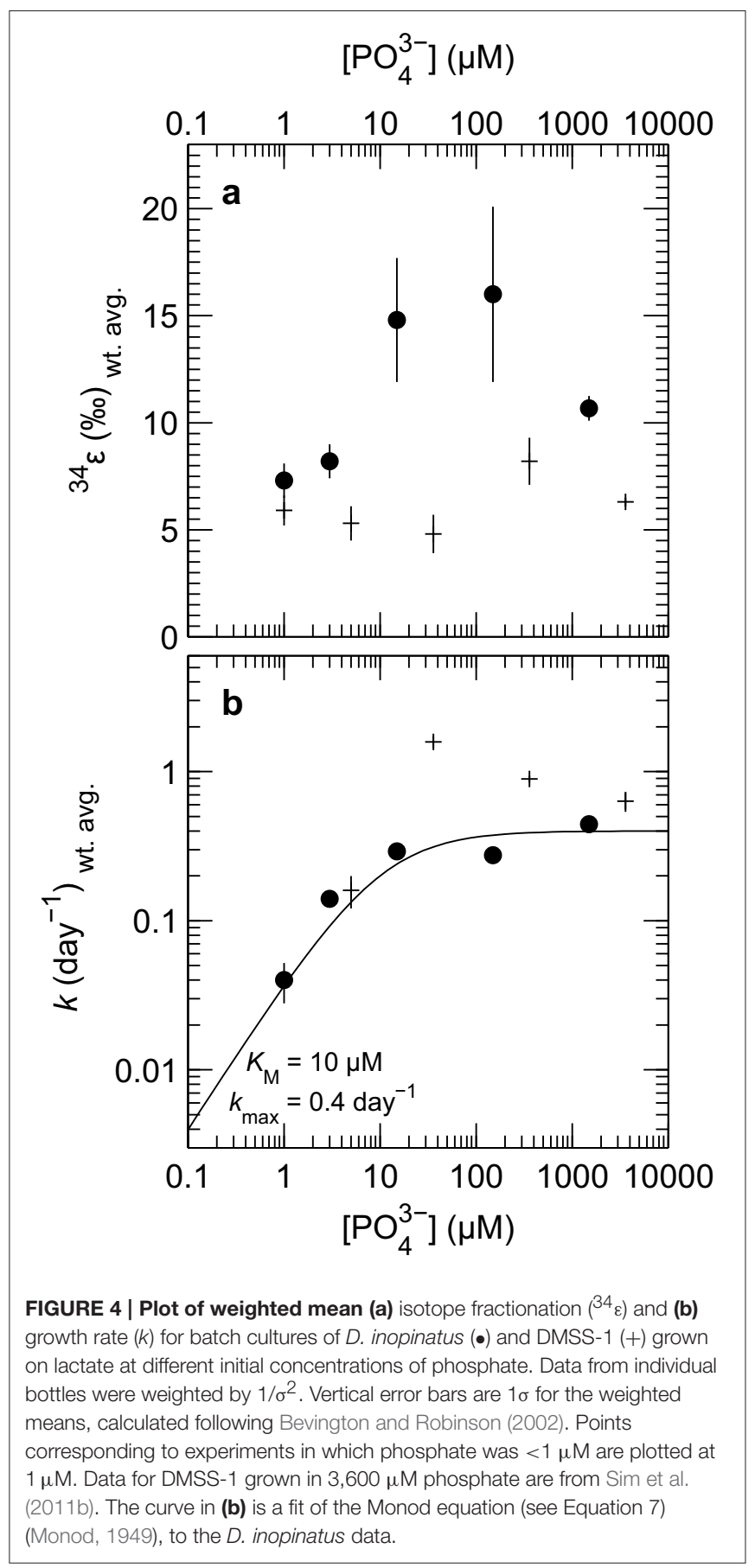

acquire phosphate during growth. Cellular yields $(Y)$ decreased by several fold at lower phosphate concentrations (Table 3). Lower cell yields were also observed by Okabe and Characklis (1992) when the phosphate concentration was about $10 \mu \mathrm{M}$ for $D$. desulfuricans grown in a chemostat; the C:P ratio of cells started to increase before the cell yield began to decrease. Thus, cells first adapted to moderately low phosphorus concentrations by reducing the cellular requirement for $\mathrm{P}$. When the phosphorus availability decreased even further, cell yields 

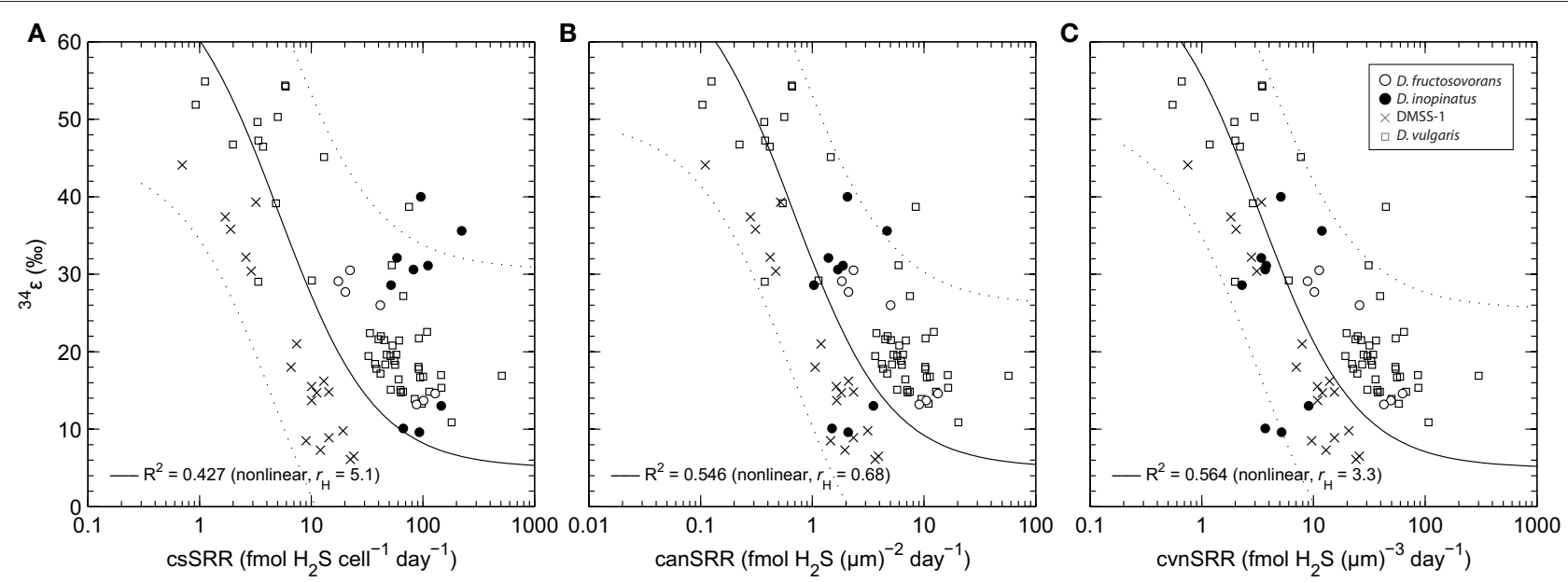

FIGURE 5 | Comparison of correlations between (a) ${ }^{34} \varepsilon$ and cell-specific sulfate reduction rate (cSSRR); (b) ${ }^{34} \varepsilon$ and cell area-normalized sulfate reduction rate (canSRR); and (c) ${ }^{34} \varepsilon$ and cell volume-normalized sulfate reduction rate (cvnSRR) for several Desulfovibrio spp. grown in culture under nutrient-replete conditions. In (a), the DMSS-1 and D. vulgaris (Hildenborough) data are from Sim et al. (2011b) and Leavitt et al. (2013), respectively. In (b,c), the sulfate reduction rates have been normalized using the cell size data shown in Table 4. The solid curve and coefficient of determination $\left(R^{2}\right)$ represent non-linear least squares fits of a model function through all data in each panel. Equations describing the curves are of the form: $y={ }^{34} \varepsilon_{\max }-x \cdot\left({ }^{34} \varepsilon_{\max }-{ }^{34} \varepsilon_{\min }\right) /\left(\mathrm{r}_{H}+x\right)$, where ${ }^{34} \varepsilon_{\max }=71 \%$ (equilibrium at $\sim 20^{\circ} \mathrm{C}$ and pH 7.0; (Millero et al., 1988; Otake et al., 2008)), ${ }^{34} \varepsilon_{\min }=5 \%$ (high-rate asymptote, see Appendix), and $r_{H}$ is a fitted parameter that has the same units as the $x$-axis (it represents the sulfate reduction rate at which ${ }^{34} \varepsilon$ is halfway between its maximum and minimum limits). This equation was chosen because it can closely approximate model results of Wing and Halevy (2014) for the typical range of csSRR observed in experiments (see Appendix), and because $R^{2}$ for fits to this equation are uniformly higher than for linear least squares regressions of ${ }^{34} \varepsilon$ against the log-transformed rates. Dotted envelope marks the non-simultaneous $95 \%$ prediction band.

began to decrease as well. Morphological changes observed in the two Desulfovibrio spp. we tested (see below), as well as structural adaptations to phosphate limitation and starvation observed in D. desulfuricans (Weimer et al., 1988) and D. alaskensis G20 (Bosak et al., 2016) are consistent with the higher bulk C:P ratio in phosphate-limited $D$. desulfuricans (Okabe and Characklis, 1992).

D. inopinatus and DMSS-1 cells elongated up to several hundred percent in the lowest phosphate conditions (Table 4). Cell elongation also occurs in phosphate limited cultures of D. alaskensis G20 (Bosak et al., 2016), albeit the overall effect in this microbe is smaller. Microscopic images of phosphatelimited D. inopinatus (Figure 2) revealed long chain-like cells as well as cells with more "typical" lengths. We attribute this cell morphology to incomplete cell division. Nucleic acids (particularly RNA, Elser et al., 2008; Yao et al., 2015) contain a very large fraction (up to tens of percent) of total cellular phosphorus; minimizing DNA and RNA synthesis and division may therefore enable survival in a competitive environment (see also Appendix). Growing phosphate-limited D. alaskensis G20 also replaces its membrane phospholipids by phosphorus-free lipids, synthesizes carbon-rich storage granules and metabolizes nucleic acids (Bosak et al., 2016). Cell elongation and the formation of intracellular carbon-rich granules may also aid in nutrient acquisition by increasing the surface area-tovolume ratio (Thingstad et al., 2005; Godwin and Cotner, 2015; Bosak et al., 2016). Also expected are decreases in the pools of phosphorus-containing metabolites dissolved in the cytoplasm: these metabolites should consist principally of inorganic phosphate, $\mathrm{P}_{\mathrm{i}}$. Below, we discuss how a diminished cytoplasmic phosphorus content can influence the kinetics of enzymatic processes and influence the correlation between ${ }^{34} \varepsilon$ and csSRR.

\section{Sulfur Isotope Fractionation}

Phosphorus-limited D. inopinatus and DMSS-1 cultures grown on lactate did not fractionate sulfur isotopes very much $(\sim 5$ to $8 \%$ ). These ${ }^{34} \varepsilon$ values were generally lower in phosphate-limited than in phosphorus-replete cultures (Figure 4a) and we did not observe a distinct correlation with csSRR. In contrast, ${ }^{34} \varepsilon$ values in DMSS-1 cultures grown in iron- and ammonium-limited media were $\sim 5$ and $\sim 1 \%$ higher relative to the cultures grown in nutrient-replete media (Sim et al., 2012). The lower selectivity of the two phosphate-limited SRB species for sulfur isotopes may be related to any number of physiological changes experienced by cells at low phosphate concentrations: the composition and appearance of cell membranes and envelopes, the accumulation of storage polymers, transport of metals and others (Bosak et al., 2016). Some possibilities that directly influence the sulfate reducing pathway are discussed below.

The fitted half-saturation constant $\left(K_{\mathrm{M}}=10 \mu \mathrm{M}\right.$, Figure 4) appears to coincide with the phosphate concentration at which the isotopic fractionation changes from $<10 \%$ to $>10 \%$ for D. inopinatus. Phosphate-limited DMSS-1 cultures exhibit ${ }^{34} \varepsilon-$ $\log _{10}(\mathrm{csSRR})$ values that fall off and plot to the right (higher csSRR) of the trend observed by Sim et al. (2011b) (Figure 6). The large heterogeneity in cell lengths of $D$. inopinatus at low phosphate concentrations (Table 4 and Figure 2) complicates interpretations of csSRR, but assuming that per-cell enzyme activities scale linearly with either cell volume or surface area, the 


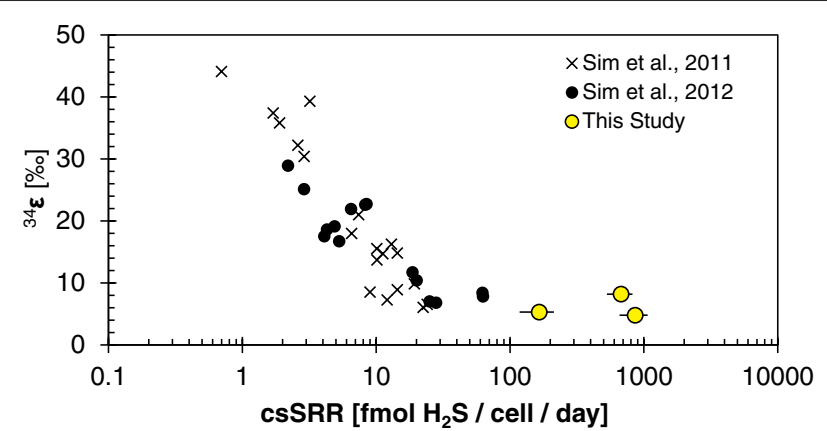

FIGURE 6 | Plot of ${ }^{34} \varepsilon$ and cell-specific sulfate reduction rate (cSSRR) observed for DMSS-1 grown on various substrates (Sim et al., 2011b), and under nutrient-limited conditions [(Sim et al., 2012) and this study].

increases in cell size (up to threefold for DMSS-1, Table 4) related to phosphate depletion cannot explain up to tenfold higher csSRRs. The elevated rates may additionally reflect changes in biochemical kinetics within the cell.

Rees (1973) introduced the reversibility of steps in the respiratory chain as a control on overall sulfur isotope fractionation, and this concept has been invoked or extended to explain features of many experimental datasets (Trudinger and Chambers, 1973; Eckert et al., 2011; Sim et al., 2011a,b; Brunner et al., 2012; Antler et al., 2017). More recently, Wing and Halevy (2014) proposed a quantitative model of dissimilatory sulfate reduction that uses enzyme kinetic and thermodynamic data to calculate ${ }^{34} \varepsilon$ values as a function of csSRR. Their model explicitly calculates reversibilities, and thereby isotopic fractionations, for each enzymatic step in MSR. This approach offers insights into links between phosphorus, the sulfate reducing pathway and sulfur isotope fractionations. Phosphoruscontaining metabolites (including the adenosine phosphates and inorganic pyrophosphate $\left(\mathrm{PP}_{\mathrm{i}}\right)$ ) influence the thermodynamic drive of reactions in the respiratory chain of sulfate reducers (Equations A1-A4), and their cytoplasmic concentrations are either assumed or explicitly predicted in their model (Figure 7b). The major conclusion of Wing and Halevy's study is that concentrations of intracellular metabolites dictate the energetic favorability and reversibility (ratio of backwards to forwards fluxes) at each step, and influence the overall sulfate reduction rate and the expression of kinetic and equilibrium isotope effects.

We reconstructed the numerical simulations of Wing and Halevy (2014), and extended them to simulate the changes in intracellular concentrations of orthophosphate $\left(\mathrm{P}_{\mathrm{i}}\right)$ and other phosphorus-containing metabolites as a function of csSRR. The most salient features of the model are described in the Appendix. Our model results suggest that high csSRRs are associated with lower phosphorus contents within the cytoplasm (Figure 7a). This is a direct consequence of Wing and Halevy's finding that reduction of adenosine-5' -phosphosulfate (APS) to sulfite (Equation A3) is the primary rate-limiting step in MSR under conditions probed by most experiments. Because $\left[\mathrm{PP}_{\mathrm{i}}\right]$ depends on $\left[\mathrm{P}_{\mathrm{i}}\right]^{2}$ (according to Equation A6), and because $\mathrm{P}_{\mathrm{i}}$ accounts for most phosphorus that is dissolved in the cytoplasm (see
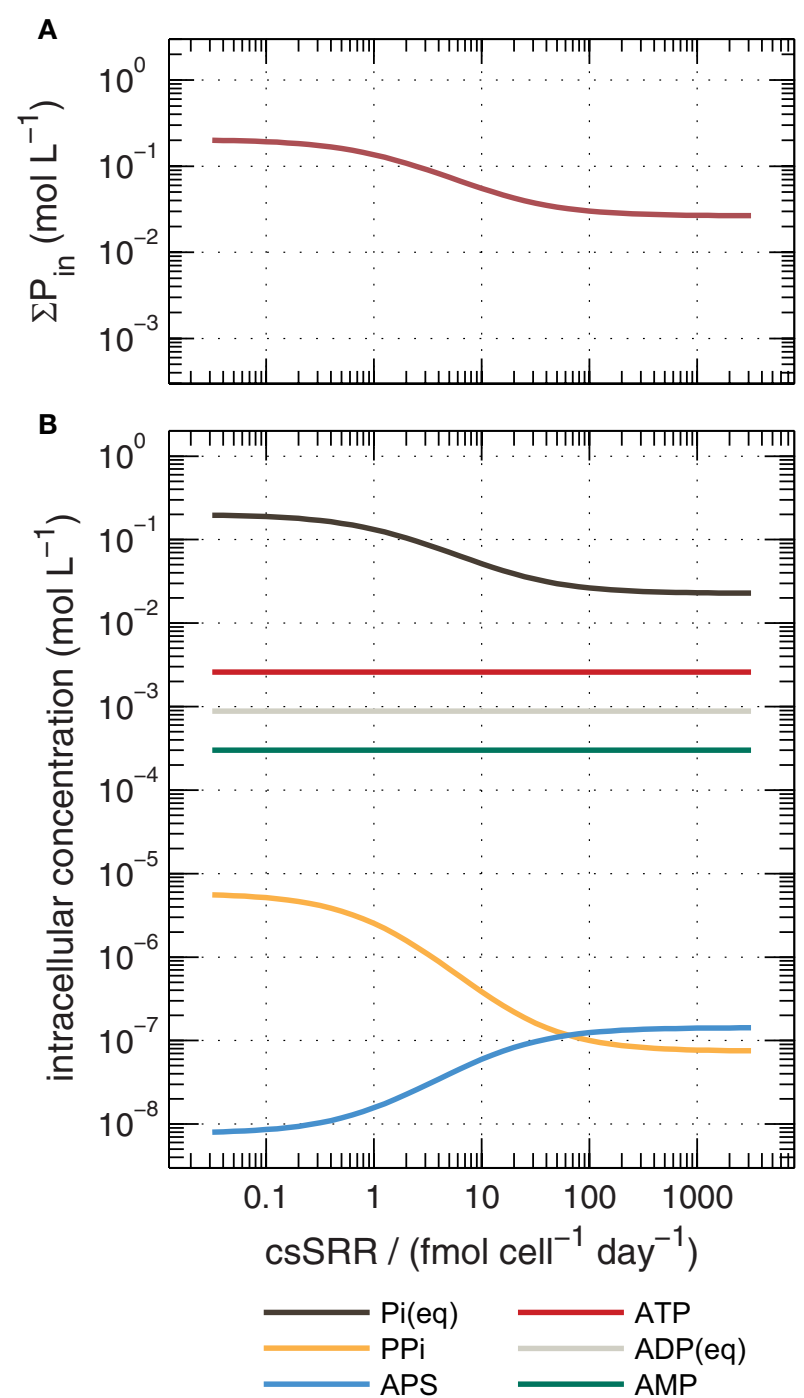

FIGURE 7 | Calculated concentrations of cytoplasmic phosphorus species during sulfate reduction by DMSS-1 predicted by an extended version of the model of Wing and Halevy (2014), described in the Appendix. Shown are (a) total intracellular phosphorus $\left(\Sigma \mathrm{P}_{\mathrm{in}}\right.$, the sum of all species in panel, b), and (b) concentrations of individual species. Calculations assumed $\left[\mathrm{SO}_{4}^{2-}\right]_{\text {out }}=20 \mathrm{mM}$ and $\left[\mathrm{H}_{2} \mathrm{~S}\right]=1 \mathrm{mM}$. $\mathrm{P}_{\mathrm{i}}$, inorganic

orthophosphate; $\mathrm{PP}_{\mathrm{i}}$, pyrophosphate; APS, adenosine-5'-phosphosulfate;

ATP, adenosine triphosphate; ADP, adenosine diphosphate; AMP, adenosine monophosphate.

discussion in Appendix), a small decrease in total cytoplasmic phosphorus during phosphorus-limited growth and starvation induces a large decrease in the $\mathrm{PP}_{\mathrm{i}}$ concentration. Lowered $\mathrm{PP}_{i}$ levels are counterbalanced by an increase in the concentration of APS (because Equation A2, sulfate activation to APS, is always near equilibrium; Sat in Figure A3a), as shown in Figure $7 \mathbf{b}$. The buildup of [APS] associated with lowered $\left[\mathrm{P}_{\mathrm{i}}\right]$ increases the thermodynamic drive for APS reduction (Equation A3). Intuitively, APS reduction becomes less reversible (Apr in Figure A3a), and therefore isotope fractionation between APS 
and the instantaneous sulfite product approaches the intrinsic kinetic isotope effect for this enzymatic step (22\% in the default model of Wing and Halevy). Because the remaining step (sulfite reduction, Equation A4) is downstream of APS reduction and is almost fully reversible ( $d S i R$ in Figure A3a), the $\delta^{34}$ S value of $\mathrm{H}_{2} \mathrm{~S}$ is not sensitive to the kinetic isotope effect assumed for $d S i R$ (in agreement with some experimental results, Leavitt et al., 2015, 2016) and is $\sim 22 \%$ lower than that of APS when csSRR is high (Figure A3b).

Modeled ${ }^{34} \varepsilon$ values asymptote to a limit of $\sim 5 \pm$ $2 \%$ at high csSRRs, in good agreement with our data from DMSS-1 cultures (Figure A4). Several assumptions built into the model require further examination to determine if they are applicable under nutrient-limited conditions. In particular, this includes the parameterization of the scaling factor

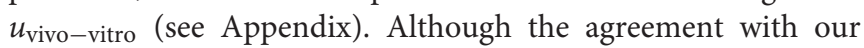
data may be circumstantial, the above treatment suggests a plausible mechanistic link between low extracellular phosphate concentrations and small ${ }^{34} \varepsilon$ both in the laboratory and in the environment. How phosphate limitation affects the fractionation of sulfur isotopes during growth on substrates that typically produce large fractionations (e.g., fructose) is an open question. The above analysis predicts a decrease in ${ }^{34} \varepsilon$ and increase in csSRR; a hypothesis that can be experimentally tested.

Studies of the sulfur cycle and the sulfur isotope record may benefit from consideration of the possible effects of phosphate limitation. While phosphorus is unlikely to limit growth of sulfate reducing bacteria in modern anoxic sediments where porewater phosphate concentrations are tens of micromolar or greater (Sundby et al., 1992), some studies hypothesize a more limited delivery flux of phosphate to Precambrian sediments (Bjerrum and Canfield, 2002; Reinhard et al., 2017). The very low sulfur isotope fractionation in sedimentary sulfates and sulfides during most of the Precambrian (Canfield, 1998) are consistent with this hypothesis. Overall, our data emphasize potential contributions of organic substrates and phosphate limitation to the persistently low sulfur isotope fractionations in the Archean and most of the Proterozoic.

\section{CONCLUSIONS}

The magnitudes of sulfur isotope fractionation by the three studied species of Desulfovibrio scale with the negative logarithm of the cell-specific sulfate reduction rate, and the trend does not appear to depend on the particular organic substrate. These findings are in agreement with previous observations from pure cultures of several other species of sulfate reducing microorganisms and support the idea that the quality of organic substrates and the availability of nutrients, particularly those involved in energy conservation, are key factors in regulating the intracellular fluxes of sulfur compounds and the expression of sulfur isotope effects during dissimilatory sulfate reduction. Clear trends appear to link sulfur isotopic fractionation and microbial sulfate reduction rates, but with large spread in the data. Normalizing the sulfate reduction rates to the cell surface area or cell volume can reduce the spread and improve the correlation between sulfur isotope fractionation and sulfate reduction rate for several Desulfovibrio spp.

The cells of two species of SRB grown on lactate elongate and form chain-like cells during phosphate limitation $(<10 \mu \mathrm{M}$ initial phosphate), their cell-specific sulfate reduction rates increase relative to the phosphate-replete cultures, and their sulfur isotope fractionations approach $\sim 5 \%$. Thus, sulfur isotope fractionation during microbial sulfate reduction in phosphorus-poor environments could deviate from predictions made under the assumption of unlimited phosphate supply. These experimental results are consistent with biochemical models that relate the kinetics and thermodynamics of enzymemediated reactions in the respiratory chain of SRB to expressed sulfur isotope effects.

\section{AUTHOR CONTRIBUTIONS}

SO, TB, SZ, and DW: Designed the study. SZ: Carried out the majority of the analytical work, analyzed the data and wrote the first draft of the manuscript. DW: Carried out analytical work and modeling. All authors contributed ideas in the interpretation of the data and wrote the final manuscript.

\section{ACKNOWLEDGMENTS}

The authors thank A. de Santiago Torio, W. Olszewski, M. S. Sim, H. Oduro, E. Molzberger, and A. Whitehill for assistance in the laboratory, and R. Summons, W. Leavitt, I. Halevy, and F. Schubotz for helpful discussions. This research was supported by the U.S. National Science Foundation (NSF EAR-1159318 to SO and TB.) and the NAI Complex Life (\#NNA08CN84A). A Simons Foundation grant to R. Summons provided additional support. SO thanks the Kerr-McGee Professorship at MIT. TB thanks the Simons Foundation Collaboration on the Origins of Life, grant \#327126. DW acknowledges support from an MIT Presidential Graduate Fellowship and the National Defense Science and Engineering Graduate (NDSEG) Fellowship.

\section{REFERENCES}

Amend, J. P., and Plyasunov, A. V. (2001). Carbohydrates in thermophile metabolism: calculation of the standard molal thermodynamic properties of aqueous pentoses and hexoses at elevated temperatures and pressures. Geochim. Cosmochim. Acta 65, 3901-3917. doi: 10.1016/S0016-7037(01) 00707-4

Antler, G., Turchyn, A. V., Ono, S., Sivan, O., and Bosak, T. (2017). Combined ${ }^{34} \mathrm{~S},{ }^{33} \mathrm{~S}$ and ${ }^{18} \mathrm{O}$ isotope fractionations record different intracellular steps of microbial sulfate reduction. Geochim. Cosmochim. Acta 203, 364-380. doi: 10.1016/j.gca.2017.01.015

Arnold, G. L., Brunner, B., Müller, I. A., and Røy, H. (2014). Modern applications for a total sulfur reduction distillation method-what's old is new again. Geochem. Trans. 15:4. doi: 10.1186/1467-4866-15-4 
Berner, R. A. (2001). Modeling atmospheric $\mathrm{O}_{2}$ over Phanerozoic time. Geochim. Cosmochim. Acta 65, 685-694. doi: 10.1016/S0016-7037(00) 00572-X

Bevington, P., and Robinson, D. K. (2002). Data Reduction and Error Analysis for the Physical Sciences, 3rd Edn. New York, NY: McGraw-Hill Education.

Bjerrum, C. J., and Canfield, D. E. (2002). Ocean productivity before about $1.9 \mathrm{Gyr}$ ago limited by phosphorus adsorption onto iron oxides. Nature 417, 159-162. doi: $10.1038 / 417159 \mathrm{a}$

Bosak, T., Schubotz, F., de Santiago Torio, A., Kuehl, J. V., Carlson, H. K., Watson, N., et al. (2016). System-wide adaptations of Desulfovibrio alaskensis G20 to phosphate-limited conditions. PLoS ONE 11:e0168719. doi: 10.1371/journal.pone.0168719

Bradley, A. S., Leavitt, W. D., Schmidt, M., Knoll, A. H., Girguis, P. R., and Johnston, D. T. (2015). Patterns of sulfur isotope fractionation during microbial sulfate reduction. Geobiology 14, 91-101. doi: 10.1111/gbi.12149

Bratbak, G., and Dundas, I. (1984). Bacterial dry matter content and biomass estimations. Appl. Environ. Microbiol. 48, 755-757.

Brüchert, V. (2004). "Physiological and ecological aspects of sulfur isotope fractionation during bacterial sulfate reduction," in Sulfur Biogeochemistry: Past And Present Geological Society of America Special Papers, eds J. P. Amend, K. J. Edwards, and T. W. Lyons (Geological Society of America), 1-16.

Brüchert, V., Knoblauch, C., and Jørgensen, B. B. (2001). Controls on stable sulfur isotope fractionation during bacterial sulfate reduction in Arctic sediments. Geochim. Cosmochim. Acta 65, 763-776. doi: 10.1016/S0016-7037(00)00557-3

Brunner, B., and Bernasconi, S. M. (2005). A revised isotope fractionation model for dissimilatory sulfate reduction in sulfate reducing bacteria. Geochim. Cosmochim. Acta 69, 4759-4771. doi: 10.1016/j.gca.2005.04.015

Brunner, B., Einsiedl, F., Arnold, G. L., Müller, I., Templer, S., and Bernasconi, S. M. (2012). The reversibility of dissimilatory sulphate reduction and the cellinternal multi-step reduction of sulphite to sulphide: insights from the oxygen isotope composition of sulphate. Isotopes Environ. Health Stud. 48, 33-54. doi: 10.1080/10256016.2011.608128

Canfield, D. (1998). A new model for Proterozoic ocean chemistry. Nature 396, 450-453. doi: 10.1038/24839

Canfield, D. E. (2001). Isotope fractionation by natural populations of sulfate-reducing bacteria. Geochim. Cosmochim. Acta 65, 1117-1124. doi: 10.1016/S0016-7037(00)00584-6

Canfield, D. E., Farquhar, J., and Zerkle, A. L. (2010). High isotope fractionations during sulfate reduction in a low-sulfate euxinic ocean analog. Geology 38, 415-418. doi: 10.1130/G30723.1

Canfield, D. E., Habicht, K. S., and Thamdrup, B. (2000). The Archean sulfur cycle and the early history of atmospheric oxygen. Science 288, 658-661. doi: 10.1126/science.288.5466.658

Canfield, D. E., Olesen, C. A., and Cox, R. P. (2006). Temperature and its control of isotope fractionation by a sulfate-reducing bacterium. Geochim. Cosmochim. Acta 70, 548-561. doi: 10.1016/j.gca.2005.10.028

Canfield, D. E., and Teske, A. (1996). Late Proterozoic rise in atmospheric oxygen concentration inferred from phylogenetic and sulphur-isotope studies. Nature 382:127. doi: $10.1038 / 382127 \mathrm{a} 0$

Canfield, D. E., and Thamdrup, B. (1994). The production of ${ }^{34}$ S-depleted sulfide during bacterial disproportionation of elemental sulfur. Science 266, 1973. doi: $10.1126 /$ science. 11540246

Chambers, L. A., Trudinger, P. A., Smith, J. W., and Burns, M. S. (1975). Fractionation of sulfur isotopes by continuous cultures of Desulfovibrio desulfuricans. Can. J. Microbiol. 21, 1602-1607. doi: 10.1139/m75-234

Chambers, L., and Trudinger, P. (1979). Microbiological fractionation of stable sulfur isotopes: a review and critique. Geomicrobiol. J. 1, 249-293. doi: $10.1080 / 01490457909377735$

Cline, J. D. (1969). Spectrophotometric determination of hydrogen sulfide in natural waters. Limnol. Oceanogr. 14, 454-458. doi: 10.4319/lo.1969.14.3.0454

Coplen, T. B. (2011). Guidelines and recommended terms for expression of stable-isotope-ratio and gas-ratio measurement results. Rapid Commun. Mass Spectrom. 25, 2538-2560. doi: 10.1002/rcm.5129

Cord-Ruwisch, R., Ollivier, B., and Garcia, J.-L. (1986). Fructose degradation by Desulfovibrio sp. in pure culture and in coculture with Methanospirillum hungatei. Curr. Microbiol. 13, 285-289. doi: 10.1007/BF01568654

Cypionka, H. (1995). "Solute transport and cell energetics," in Sulfate-Reducing Bacteria, ed L. L. Barton (New York, NY: Springer Nature), 151-184.
Dalla-Betta, P., and Schulte, M. (2009). Calculation of the aqueous thermodynamic properties of citric acid cycle intermediates and precursors and the estimation of high temperature and pressure equation of state parameters. Int. J. Mol. Sci. 10, 2809-2837. doi: 10.3390/ijms10062809

Detmers, J., Brüchert, V., Habicht, K. S., and Kuever, J. (2001). Diversity of sulfur isotope fractionations by sulfate-reducing prokaryotes. Appl. Environ. Microbiol. 67, 888-894. doi: 10.1128/AEM.67.2.888-894.2001

Dick, J. M. (2008). Calculation of the relative metastabilities of proteins using the CHNOSZ software package. Geochem. Trans. 9:10. doi: 10.1186/1467-4866-9-10

Eckert, T., Brunner, B., Edwards, E., and Wortmann, U. (2011). Microbially mediated re-oxidation of sulfide during dissimilatory sulfate reduction by Desulfobacter latus. Geochim. Cosmochim. Acta 75, 3469-3485. doi: 10.1016/j.gca.2011.03.034

Elser, J. J., Sterner, R. W., Gorokhova, E., Fagan, W. F., Markow, T. A., Cotner, J. B., et al. (2008). Biological stoichiometry from genes to ecosystems. Ecol. Lett. 3, 540-550. doi: 10.1111/j.1461-0248.2000.00185.x

Fagerbakke, K. M., Heldal, M., and Norland, S. (1996). Content of carbon, nitrogen, oxygen, sulfur and phosphorus in native aquatic and cultured bacteria. Aquat. Microb. Ecol. 10, 15-27. doi: 10.3354/ame010015

Forrest, J., and Newman, L. (1977). Silver-110 microgram sulfate analysis for the short time resolution of ambient levels of sulfur aerosol. Anal. Chem. 49, 1579-1584. doi: 10.1021/ac50019a030

Garrels, R. M., and Lerman, A. (1981). Phanerozoic cycles of sedimentary carbon and sulfur. Proc. Natl. Acad. Sci. U.S.A. 78, 4652-4656. doi: $10.1073 /$ pnas.78.8.4652

Godwin, C. M., and Cotner, J. B. (2015). Stoichiometric flexibility in diverse aquatic heterotrophic bacteria is coupled to differences in cellular phosphorus quotas. Front. Microbiol. 6:159. doi: 10.3389/fmicb.2015.00159

Habicht, K. S., and Canfield, D. E. (2001). Isotope fractionation by sulfate-reducing natural populations and the isotopic composition of sulfide in marine sediments. Geology 29, 555-558. doi: 10.1130/0091-7613(2001)029<0555:IFBSRN>2.0.CO;2

Habicht, K. S., Gade, M., Thamdrup, B., Berg, P., and Canfield, D. E. (2002). Calibration of sulfate levels in the Archean ocean. Science 298, 2372-2374. doi: $10.1126 /$ science. 1078265

Harrison, A., and Thode, H. (1958). Mechanism of the bacterial reduction of sulphate from isotope fractionation studies. Trans. Faraday Soc. 54, 84-92. doi: $10.1039 /$ tf9585400084

Hauser, L. J., Land, M. L., Brown, S. D., Larimer, F., Keller, K. L., RappGiles, B. J., et al. (2011). Complete genome sequence and updated annotation of Desulfovibrio alaskensis G20. J. Bacteriol. 193, 4268-4269. doi: 10.1128/JB.05400-11

Heidelberg, J. F., Seshadri, R., Haveman, S. A., Hemme, C. L., Paulsen, I. T., Kolonay, J. F., et al. (2004). The genome sequence of the anaerobic, sulfatereducing bacterium Desulfovibrio vulgaris Hildenborough. Nat. Biotechnol. 22, 554-559. doi: 10.1038/nbt959

Hoek, J., Reysenbach, A.-L., Habicht, K. S., and Canfield, D. E. (2006). Effect of hydrogen limitation and temperature on the fractionation of sulfur isotopes by a deep-sea hydrothermal vent sulfate-reducing bacterium. Geochim. Cosmochim. Acta 70, 5831-5841. doi: 10.1016/j.gca.2006.07.031

Holland, H. D. (1973). Systematics of the isotopic composition of sulfur in the oceans during the Phanerozoic and its implications for atmospheric oxygen. Geochim. Cosmochim. Acta 37, 2605-2616. doi: 10.1016/0016-7037(73) 90268-8

Imhoff-Stuckle, D., and Pfennig, N. (1983). Isolation and characterization of a nicotinic acid-degrading sulfate-reducing bacterium, Desulfococcus niacini $\mathrm{sp}$. nov. Arch. Microbiol. 136, 194-198. doi: 10.1007/BF00409843

Johnson, J. W., Oelkers, E. H., and Helgeson, H. C. (1992). SUPCRT92: a software package for calculating the standard molal thermodynamic properties of minerals, gases, aqueous species, and reactions from 1 to 5000 bar and 0 to 1000 C. Comput. Geosci. 18, 899-947. doi: 10.1016/0098-3004(92)90029-Q

Johnston, D. T., Farquhar, J., and Canfield, D. E. (2007). Sulfur isotope insights into microbial sulfate reduction: when microbes meet models. Geochim. Cosmochim. Acta 71, 3929-3947. doi: 10.1016/j.gca.2007.05.008

Johnston, D. T., Wing, B. A., Farquhar, J., Kaufman, A. J., Strauss, H., Lyons, T. W., et al. (2005). Active microbial sulfur disproportionation in the Mesoproterozoic. Science 310, 1477-1479. doi: 10.1126/science.1117824 
Jones, W. J., Guyot, J.-P., and Wolfe, R. S. (1984). Methanogenesis from sucrose by defined immobilized consortia. Appl. Environ. Microbiol. 47, 1-6.

Jorgensen, B. B. (1979). A theoretical model of the stable sulfur isotope distribution in marine sediments. Geochim. Cosmochim. Acta 43, 363-374. doi: 10.1016/0016-7037(79)90201-1

Jørgensen, B. B. (1982). Mineralization of organic matter in the sea bed-the role of sulphate reduction. Nature 296, 643-645. doi: 10.1038/296643a0

Kaplan, I., Emery, K., and Rittenberg, S. (1963). The distribution and isotopic abundance of sulphur in recent marine sediments off southern California. Geochim. Cosmochim. Acta 27, 297-331. doi: 10.1016/0016-7037(63)90074-7

Kaplan, I., and Rittenberg, S. (1964). Microbiological fractionation of sulphur isotopes. J. Gen. Microbiol. 34, 195-212. doi: 10.1099/00221287-34-2-195

Kleikemper, J., Schroth, M. H., Bernasconi, S. M., Brunner, B., and Zeyer, J. (2004). Sulfur isotope fractionation during growth of sulfate-reducing bacteria on various carbon sources. Geochim. Cosmochim. Acta 68, 4891-4904. doi: 10.1016/j.gca.2004.05.034

Kligler, I., and Guggenheim, K. (1938). The influence of vitamin C on the growth of anaerobes in the presence of air, with special reference to the relative significance of $\mathrm{E}_{\mathrm{h}}$ and $\mathrm{O}_{2}$ in the growth of anaerobes. J. Bacteriol. 35, 141-156.

$\mathrm{Ku}, \mathrm{H}$. (1969). Notes on the use of propagation of error formulas. J. Res. Nat. Bur. Stand. C 70C, 263-273

Leavitt, W. D., Bradley, A. S., Santos, A. A., Pereira, I. A. C., and Johnston, D. T. (2015). Sulfur isotope effects of dissimilatory sulfite reductase. Front. Microbiol. 6:1392. doi: $10.3389 /$ fmicb.2015.01392

Leavitt, W. D., Halevy, I., Bradley, A. S., and Johnston, D. T. (2013). Influence of sulfate reduction rates on the Phanerozoic sulfur isotope record. Proc. Natl. Acad. Sci. U.S.A. 110, 11244-11249. doi: 10.1073/pnas.1218874110

Leavitt, W. D., Venceslau, S. S., Pereira, I. A. C., Johnston, D. T., and Bradley, A. S. (2016). Fractionation of sulfur and hydrogen isotopes in Desulfovibrio vulgaris with perturbed DsrC expression. FEMS Microbiol. Lett. 363:fnw226. doi: 10.1093/femsle/fnw226

Luo, G., Ono, S., Beukes, N. J., Wang, D. T., Xie, S., and Summons, R. E. (2016). Rapid oxygenation of Earth's atmosphere 2.33 billion years ago. Sci. Adv. 2:e1600134. doi: 10.1126/sciadv.1600134

Millero, F. J., Plese, T., and Fernandez, M. (1988). The dissociation of hydrogen sulfide in seawater. Limnol. Oceanogr. 33, 269-274. doi: 10.4319/lo.1988.33.2.0269

Monod, J. (1949). The growth of bacterial cultures. Ann. Rev. Microbiol. 3, 371-394. doi: 10.1146/annurev.mi.03.100149.002103

Muyzer, G., and Stams, A. J. (2008). The ecology and biotechnology of sulphatereducing bacteria. Nat. Rev. Microbiol. 6, 441-454. doi: 10.1038/nrmicro1892

Neretin, L. N., Schippers, A., Pernthaler, A., Hamann, K., Amann, R., and Jørgensen, B. B. (2003). Quantification of dissimilatory (bi)sulphite reductase gene expression in Desulfobacterium autotrophicum using realtime RT-PCR. Environ. Microbiol. 5, 660-671. doi: 10.1046/j.1462-2920.2003. 00452.x

Noble, R. T., and Fuhrman, J. A. (1998). Use of SYBR Green I for rapid epifluorescence counts of marine viruses and bacteria. Aquat. Microb. Ecol. 14, 113-118. doi: 10.3354/ame014113

Okabe, S., and Characklis, W. G. (1992). Effects of temperature and phosphorous concentration on microbial sulfate reduction by Desulfovibrio desulfuricans. Biotechnol. Bioeng. 39, 1031-1042. doi: 10.1002/bit.260391007

Ollivier, B., Cord-Ruwisch, R., Hatchikian, E., and Garcia, J.-L. (1988). Characterization of Desulfovibrio fructosovorans sp. nov. Arch. Microbiol. 149, 447-450. doi: 10.1007/BF00425586

Ono, S., Wing, B., Johnston, D., Farquhar, J., and Rumble, D. (2006). Massdependent fractionation of quadruple stable sulfur isotope system as a new tracer of sulfur biogeochemical cycles. Geochim. Cosmochim. Acta 70, 2238-2252. doi: 10.1016/j.gca.2006.01.022

Otake, T., Lasaga, A. C., and Ohmoto, H. (2008). Ab initio calculations for equilibrium fractionations in multiple sulfur isotope systems. Chem. Geol. 249, 357-376. doi: 10.1016/j.chemgeo.2008.01.020

Peck, H. (1960). Evidence for oxidative phosphorylation during the reduction of sulfate with hydrogen by Desulfovibrio desulfuricans. J. Biol. Chem. 235, 2734-2738.

Planavsky, N. J., Rouxel, O. J., Bekker, A., Lalonde, S. V., Konhauser, K. O., Reinhard, C. T., et al. (2010). The evolution of the marine phosphate reservoir. Nature 467, 1088-1090. doi: 10.1038/nature09485
Pomeroy, L. R. B., Williams, P., le., Azam, F., and Hobbie, J. E. (2007). The microbial loop. Oceanography 20:28. doi: 10.5670/oceanog.2007.45

Postgate, J. R. (1979). The Sulphate-Reducing Bacteria. Cambridge, UK: CUP Archive.

Rees, C. E. (1973). A steady-state model for sulphur isotope fractionation in bacterial reduction processes. Geochim. Cosmochim. Acta 37, 1141-1162. doi: 10.1016/0016-7037(73)90052-5

Reichenbecher, W., and Schink, B. (1997). Desulfovibrio inopinatus, sp. nov., a new sulfate-reducing bacterium that degrades hydroxyhydroquinone $(1,2$, 4-trihydroxybenzene). Arch. Microbiol. 168, 338-344. doi: 10.1007/s0020300 50507

Reinhard, C. T., Planavsky, N. J., Gill, B. C., Ozaki, K., Robbins, L. J., Lyons, T. W., et al. (2017). Evolution of the global phosphorus cycle. Nature 541, 386-389. doi: $10.1038 /$ nature 20772

Rudnicki, M. D., Elderfield, H., and Spiro, B. (2001). Fractionation of sulfur isotopes during bacterial sulfate reduction in deep ocean sediments at elevated temperatures. Geochim. Cosmochim. Acta 65, 777-789. doi: 10.1016/S0016-7037(00)00579-2

Sass, A., Rütters, H., Cypionka, H., and Sass, H. (2002). Desulfobulbus mediterraneus sp. nov., a sulfate-reducing bacterium growing on monoand disaccharides. Arch. Microbiol. 177, 468-474. doi: 10.1007/s00203-0020415-5

Shen, Y., and Buick, R. (2004). The antiquity of microbial sulfate reduction. Earth Sci. Rev. 64, 243-272. doi: 10.1016/S0012-8252(03)00054-0

Shock, E. L. (1995). Organic acids in hydrothermal solutions: standard molal thermodynamic properties of carboxylic acids and estimates of dissociation constants at high temperatures and pressures. Am. J. Sci. 295:496. doi: 10.2475/ajs.295.5.496

Shock, E. L., and Helgeson, H. C. (1988). Calculation of the thermodynamic and transport properties of aqueous species at high pressures and temperatures: correlation algorithms for ionic species and equation of state predictions to $5 \mathrm{~kb}$ and 1000 C. Geochim. Cosmochim. Acta 52, 2009-2036. doi: 10.1016/0016-7037(88)90181-0

Sim, M. S., Bosak, T., and Ono, S. (2011a). Large sulfur isotope fractionation does not require disproportionation. Science 333, 74-77. doi: $10.1126 /$ science. 1205103

Sim, M. S., Ono, S., and Bosak, T. (2012). Effects of iron and nitrogen limitation on sulfur isotope fractionation during microbial sulfate reduction. Appl. Environ. Microbiol. 78, 8368-8376. doi: 10.1128/AEM.01842-12

Sim, M. S., Ono, S., Donovan, K., Templer, S. P., and Bosak, T. (2011b). Effect of electron donors on the fractionation of sulfur isotopes by a marine Desulfovibrio sp. Geochim. Cosmochim. Acta 75, 4244-4259. doi: 10.1016/j.gca.2011.05.021

Sim, M. S., Wang, D. T., Zane, G. M., Wall, J. D., Bosak, T., and Ono, S. (2013). Fractionation of sulfur isotopes by Desulfovibrio vulgaris mutants lacking hydrogenases or type I tetraheme cytochrome c3. Front. Microbiol. 4:171. doi: 10.3389/fmicb.2013.00171

Sundby, B., Gobeil, C., Silverberg, N., and Alfonso, M. (1992). The phosphorus cycle in coastal marine sediments. Limnol. Oceanogr. 37, 1129-1145. doi: 10.4319/lo.1992.37.6.1129

Thauer, R. K., Jungermann, K., and Decker, K. (1977). Energy conservation in chemotrophic anaerobic bacteria. Bacteriol. Rev. 41:100.

Thingstad, T. F., Øvreås, L., Egge, J. K., Løvdal, T., and Heldal, M. (2005). Use of non-limiting substrates to increase size; a generic strategy to simultaneously optimize uptake and minimize predation in pelagic osmotrophs? Ecol. Lett. 8, 675-682. doi: 10.1111/j.1461-0248.2005.00768.x

Thode, H., Macnamara, J., and Fleming, W. (1953). Sulphur isotope fractionation in nature and geological and biological time scales. Geochim. Cosmochim. Acta 3, 235-243. doi: 10.1016/0016-7037(53)90042-8

Thode, H., Monster, J., and Dunford, H. (1961). Sulphur isotope geochemistry. Geochim. Cosmochim. Acta 25, 159-174. doi: 10.1016/0016-7037(61)90074-6

Trudinger, P. A., and Chambers, L. A. (1973). Reversibility of bacterial sulfate reduction and its relevance to isotope fractionation. Geochim. Cosmochim. Acta 37, 1775-1778. doi: 10.1016/0016-7037(73)90162-2

Tudge, A. P., and Thode, H. (1950). Thermodynamic properties of isotopic compounds of sulphur. Can. J. Res. 28, 567-578. doi: 10.1139/cjr50b-069

Van Mooy, B. A. S., Fredricks, H. F., Pedler, B. E., Dyhrman, S. T., Karl, D. M., Kobližek, M., et al. (2009). Phytoplankton in the ocean use 
Zaarur et al.

Phosphate, SRB Morphology, and ${ }^{34} \mathrm{~S} /{ }^{32} \mathrm{~S}$

non-phosphorus lipids in response to phosphorus scarcity. Nature 458, 69-72. doit: 10.1038/nature07659

Wagner, W., and Pruß, A. (2002). The IAPWS formulation 1995 for the thermodynamic properties of ordinary water substance for general and scientific use. J. Phys. Chem. Ref. Data 31, 387-535. do: 10.1063/1.1461829

Weimer, P. J., Van Kavelaar, M. J., Michel, C. B., and Kg, T. K. (1988). Effect of phosphate on the corrosion of carbon steel and on the composition of corrosion products in two-stage continuous cultures of Desulfovibrio desulfuricans. Apple. Environ. Microbial. 54, 386-396.

Westrich, J. T., and Berner, R. A. (1984). The role of sedimentary organic matter in bacterial sulfate reduction: the G model tested. Limnol. Oceanog. 29, 236-249. dor: 10.4319/lo.1984.29.2.0236

Widdel, F., and Hansen, T. (1992). "The dissimilatory sulfate-and sulfur-reducing bacteria," in The Prokaryotes: A Handbook on the Biology of Bacteria: Ecophysiology, Isolation, Identification, Applications, Vol. 1, eds A. Blows, H. Truer, M. Dworkin, W. Harder, and K. Schleifer (New York, NY: SpringerVerlag Inc.), 582-624.

Widdel, F., and Pfennig, N. (1981). Studies on dissimilatory sulfate-reducing bacteria that decompose fatty acids: I. Isolation of new sulfate-reducing bacteria enriched with acetate from saline environments. Description of Desulfobacter postgatei gen. nov., sp. nov. Arch. Microbiol. 129, 395-400. do: 10.1007/BF00406470

Wing, B. A., and Halevy, I. (2014). Intracellular metabolite levels shape sulfur isotope fractionation during microbial sulfate respiration. Proc.
Natl. Scad. Sci. U.S.A. 111, 18116-18125. do: 10.1073/pnas.14075 02111

Wortmann, U. G., Bernasconi, S. M., and Böttcher, M. E. (2001). Hypersulfidic deep biosphere indicates extreme sulfur isotope fractionation during single-step microbial sulfate reduction. Geology 29, 647-650. do: 10.1130/0091-7613(2001)029<0647:HDBIES $>$ 2.0.CO;2

Yo, M., Elling, F. J., Jones, C., Nomosatryo, S., Long, C. P., Crowe, S. A., et al. (2015). Heterotrophic bacteria from an extremely phosphate-poor lake have conditionally reduced phosphorus demand and utilize diverse sources of phosphorus. Environ. Microbial. 18, 656-667. doa: 10.1111/1462-2920. 13063

Conflict of Interest Statement: The authors declare that the research was conducted in the absence of any commercial or financial relationships that could be construed as a potential conflict of interest.

Copyright (c) 2017 Zaarur, Wang, Ono and Borak. This is an open-access article distributed under the terms of the Creative Commons Attribution License (CC $B Y)$. The use, distribution or reproduction in other forums is permitted, provided the original author (s) or licenser are credited and that the original publication in this journal is cited, in accordance with accepted academic practice. No use, distribution or reproduction is permitted which does not comply with these terms.

Frontiers in Microbiology | www.frontiersin.org

17

May 2017 | Volume 8 | Article 890 


\section{APPENDIX}

\section{Cellular Distribution of Phosphorus in SRB}

Using literature data, we can roughly estimate the amounts of phosphorus contained in (i) metabolites dissolved in cytoplasm $\left(\Sigma \mathrm{P}_{\text {in }}\right)$, (ii) in nucleic acids (DNA, RNA), and (iii) in lipid membranes of SRB cells. (i) Inorganic phosphate $\left(\mathrm{P}_{\mathrm{i}}\right)$, calculated from a biochemical model of dissimilatory sulfate reduction (described below), ranges between ca. $10^{-2}$ and $10^{-1} \mathrm{M}$ intracellularly and comprises the majority of $\Sigma \mathrm{P}_{\text {in }}$ (Figure 7). This range is consistent with limited experimental data for other bacteria (Thauer et al., 1977, and references therein). A $\sim 1 \mu \mathrm{m}^{3}$ cell $\left(=1 \times 10^{-15} \mathrm{~L}\right)$, typical of healthy DMSS-1 cells, would therefore contain between 0.01 and $0.1 \mathrm{fmol}$ of $\Sigma \mathrm{P}_{\text {in }}$. Cells of other SRB we studied are typically 2-20 times larger (Table 4) and would contain proportionally more $\Sigma \mathrm{P}_{\text {in }}$. (ii) The phosphorus in genomic DNA can be estimated from the size of the bacterial genome. A cell with a $\sim 3.6 \mathrm{Mbp}$ genome, typical of Desulfovibrio spp. (Heidelberg et al., 2004; Hauser et al., 2011), would have 0.012 fmol $\mathrm{P}$ in its genomic DNA. ${ }^{2}$ Additional phosphorus is found within the nucleic acids in plasmids and RNA. RNA, in particular, can contain up to 25 times more phosphorus than genomic DNA in SRB (Postgate, 1979). (iii) Phospholipids can contain as much cellular phosphorus as genomic DNA (Van Mooy et al., 2009). The lipid phosphorus inventory is highly flexible, as evidenced by near-total replacement of phospholipids by phosphorus-free lipids in phosphate-limited SRB cultures (Bosak et al., 2016).

Total phosphorus content is the sum of these fractions $\left(=\Sigma \mathrm{P}_{\text {in }}+\mathrm{P}_{\text {nucleic acids }}+\mathrm{P}_{\text {lipids }}\right)$ and can also be estimated independently from C:P ratios. For a $\sim 1 \mu \mathrm{m}^{3}$ cell, which is typical for healthy DMSS-1 cells (Table 4), and assuming a cellular carbon-to-volume ratio of $0.22 \mathrm{~g} \mathrm{C} \mathrm{cm}^{-3}$ (or $220 \mathrm{fg}$ C $\mu \mathrm{m}^{-3}$; Bratbak and Dundas, 1984) and atomic C:P ratio of 100:1 (Fagerbakke et al., 1996) ${ }^{3}$ yields a total phosphorus content of $0.2 \mathrm{fmol} \mathrm{P}^{\mathrm{P}} \mathrm{cell}^{-1}$. This is similar to the sum of the above components. Due to the wide variation in cell size and $\mathrm{C}: \mathrm{P}$ ratios amongst species and growth conditions, estimated inventories are probably accurate to no better than a factor of 10. A population of $1 \times 10^{7}$ cells $/ \mathrm{ml}$ would therefore require at least $2 \mu \mathrm{M}$ phosphorus to synthesize all cellular components, a number that is of the same order of magnitude as phosphate concentrations $(\sim 10 \mu \mathrm{M})$ at which we and others have observed growth to be limiting in SRB cells.

\section{Intracellular Phosphorus and Sulfur Isotope Fractionation}

We calculated intracellular concentrations of phosphorus and the sulfur isotope fractionation factor $\left({ }^{34} \varepsilon\right)$ as a function of $\operatorname{csSRR}$, following the approach of Wing and Halevy (2014). Here, we briefly review key features of their numerical model, and then discuss some implications for phosphate metabolism in SRB.

\footnotetext{
${ }^{2}$ Sequences from the DOE Joint Genome Institute (JGI) show that genomes of DMSS-1 (4.7 Mbp) and D. inopinatus (5.8 Mbp) are somewhat larger.

${ }^{3}$ Reported C:P ranges from 20:1 for Desulfovibrio desulfuricans (Okabe and Characklis, 1992) to 500:1 for D. vulgaris Hildenborough (Postgate, 1979).
}

Sulfate reduction is treated in four reversible enzymaticallymediated steps ${ }^{4}$ in the model of Wing and Halevy:

$$
\begin{aligned}
\mathrm{SO}_{4}^{2-}{ }_{\text {out }}+n \mathrm{H}^{+}{ }_{\text {out }} & \rightleftharpoons \mathrm{SO}_{4}^{2-}{ }_{\text {in }}+n \mathrm{H}^{+}{ }_{\text {in }} \\
\mathrm{SO}_{4}^{2-}{ }_{\text {in }}+\mathrm{ATP} & \rightleftharpoons \mathrm{APS}+\mathrm{PP}_{\mathrm{i}} \\
\mathrm{APS}+\mathrm{MK}_{\text {red }} & \rightleftharpoons \mathrm{SO}_{3}^{2-}+\mathrm{MK}_{\text {ox }}+\mathrm{AMP} \\
\mathrm{SO}_{3}^{2-}+\mathrm{MK}_{\text {red }} & \rightleftharpoons \mathrm{H}_{2} \mathrm{~S}+\mathrm{MK}_{\text {ox }}
\end{aligned}
$$

Enzymes that mediate the reactions in Equations A1-A4 are (respectively), sulfate permeases/transporters (SulP family), sulfate adenylyltransferase (Sat), APS reductase (Apr), and dissimilatory sulfite reductase ( $\mathrm{dSiR})$.

For given values of csSRR, the model yields predictions of steady-state intracellular concentrations of pyrophosphate $\left(\mathrm{PP}_{\mathrm{i}}\right)$, adenosine- $5^{\prime}$-phosphosulfate (APS), and sulfite $\left(\mathrm{SO}_{3}^{2-}\right)$. Several variables have to be specified. Those most relevant to our study are $\left[\mathrm{SO}_{4}^{2-}\right]_{\text {out }}$, the extracellular sulfate concentration; $\left[\mathrm{H}_{2} \mathrm{~S}\right]$, the sulfide concentration; concentrations of adenosine triphosphate (ATP) and adenosine monophosphate (AMP); and $u_{\text {vivo-vitro, a }}$ scaling factor to account for differences in enzyme concentrations between intact cells and cell extracts studied in enzyme kinetic experiments. The first two parameters can be constrained by batch culture experiments. ATP and AMP concentrations are held constant (at 2.6 and $0.3 \mathrm{mM}$, respectively), as are concentrations of the reduced/oxidized forms of the electron carrier (menaquinone, MK in Equations A3, A4). The remaining parameter $u_{\text {vivo-vitro }}$ (intended as the ratio of enzyme activities in live SRB cells to enzyme activities in whole cell extracts) was calibrated by Wing and Halevy for DMSS-1 and several other species by fitting model results to isotopic data from pure cultures. We note that Wing and Halevy formulated $u_{\text {vivo-vitro }}$ as a linear function of csSRR (i.e., $u_{\text {vivo-vitro }}=m \times \operatorname{csSRR}+b$, where $m$ and $b$ are constants chosen to fit ${ }^{34} \varepsilon-$ csSRR data for each species). Asymptotic behavior at high values of csSRR, where $b \ll m \times c s S R R$, results from this parameterization. Although some evidence supports this scaling of gene expression with csSRR (Neretin et al., 2003; Wing and Halevy, 2014), it is unclear at present whether this relationship holds under phosphoruslimited conditions, as it would require high concentrations of enzymes under phosphorus stress. The biological reasons, if any, for this currently enforced asymptotic behavior requires further study.

Results of the model calculations are shown in Figures $7 \mathbf{B}$, A3, A4. We noted several important features of the model results: (i) Most of the change in ${ }^{34} \varepsilon$ [the linear portion of the $1 \mathrm{mM} \mathrm{H}_{2} \mathrm{~S}$ curve on the ${ }^{34} \varepsilon-\log _{10}$ (csSRR) plot in Figure A4B] occurs at csSRRs between 0.1 and $10 \mathrm{fmol} \mathrm{cell}^{-1} \mathrm{day}^{-1}$; below this range, ${ }^{34} \varepsilon$ approaches its thermodynamic value of $\sim 71 \%$; (Tudge and Thode, 1950), and above $10 \mathrm{fmol} \mathrm{cell}^{-1}$ day $^{-1}$, ${ }^{34} \varepsilon$ asymptotically approaches a range between 3 and $7 \%$; (ii) Over the range of csSRRs from 0.1 to $100 \mathrm{fmol} \mathrm{cell}^{-1}$ day $^{-1}$ ], concentrations of $\mathrm{PP}_{\mathrm{i}}$ decrease by 100 -fold, and [APS]

\footnotetext{
${ }^{4}$ In these chemical equations, missing charges would be balanced by $\mathrm{H}^{+}$and $\mathrm{H}_{2} \mathrm{O}$, which do not appear in the reaction quotient when biochemical standard states are used and $\mathrm{pH}$ is assumed to be 7.0 , as has been done here.
} 
increases by 10 -fold. (iii) Between 10 and $100 \mathrm{fmol} \mathrm{cell}^{-1} \mathrm{day}^{-1}$, concentrations of $\mathrm{PP}_{\mathrm{i}}$ and APS are still sensitive to changes in $\operatorname{csSRR}$, but ${ }^{34} \varepsilon$ is not very sensitive (compare Figures $7 \mathbf{B}$, A4B). This is because the reversibility of the process described by Equation $\mathrm{A} 3$ is insensitive to csSRR in this range ( $\mathrm{Apr}$ in Figure A3a); the variation in ${ }^{34} \varepsilon$ with csSRR here is driven mostly by the changes in the reversibility of sulfate uptake (Equation A1), which retains some sensitivity to csSRR in this range (SulP in Figure A3a).

We extended the Wing and Halevy model to calculate inorganic phosphate $\left(\mathrm{P}_{\mathrm{i}}\right)$ and adenosine diphosphate (ADP) concentrations (Figure 7B). The model assumes that the concentrations of these species are governed by the following two equilibria (Thauer et al., 1977):

$$
\begin{aligned}
\mathrm{ATP}+\mathrm{AMP} & \rightleftharpoons 2 \mathrm{ADP}, \quad \Delta_{\mathrm{r}} G^{\circ \prime}=0 \mathrm{~kJ} \mathrm{~mol}^{-1} \\
\mathrm{PP}_{i}+\mathrm{H}_{2} \mathrm{O} & \rightleftharpoons 2 \mathrm{P}_{i}, \quad \Delta_{\mathrm{r}} G^{\circ \prime}=-21.9 \mathrm{~kJ} \mathrm{~mol}^{-1}
\end{aligned}
$$

Because these reactions are catalyzed by efficient enzymes (adenylate kinase and pyrophosphatase, respectively; Cypionka,
1995), equilibrium is probably approached or attained under most growth conditions. Moderate deviations from the assumption of equilibrium do not influence the prediction of decreasing $\Sigma \mathrm{P}_{\text {in }}$ with higher csSRR shown in Figure 7A, because $\mathrm{P}_{\mathrm{i}}$ makes up the majority of $\Sigma \mathrm{P}_{\text {in }}$ and exceeds the next most abundant species, ATP, by one or more orders of magnitude. In the model, decreased $\left[\mathrm{P}_{\mathrm{i}}\right]$ accommodates nearly the entirety of the decrease in $\Sigma \mathrm{P}_{\text {in }}$, leaving the concentrations of adenosine phosphates unchanged (Figure 7B); this behavior is consistent with observations that the adenylate energy charge of cells remains nearly constant over a range of physiological states (Thauer et al., 1977). However, absolute concentrations of $\mathrm{P}_{\mathrm{i}}$, $\mathrm{PP}_{\mathrm{i}}$, and APS are sensitive to order-of-magnitude variations in $\left[\mathrm{SO}_{4}^{2-}\right]_{\text {out }}$ and $\left[\mathrm{H}_{2} \mathrm{~S}\right]$ (Wing and Halevy, 2014). Of particular note is that $\left[\mathrm{PP}_{\mathrm{i}}\right]$ is highly sensitive to $\left[\mathrm{P}_{\mathrm{i}}\right]$ (Equation $\mathrm{A} 6$ ), so $\mathrm{PP}_{\mathrm{i}}$ concentrations will be suppressed to very low levels when phosphate levels inside the cell are low. Because $\mathrm{PP}_{\mathrm{i}}$ is a product of the reaction for sulfate activation by ATP (Equation A2), low $\left[\mathrm{PP}_{\mathrm{i}}\right]$ increases the thermodynamic favorability of this reaction and pulls it toward the right (lower reversibility). 


\section{D. inopinatus}
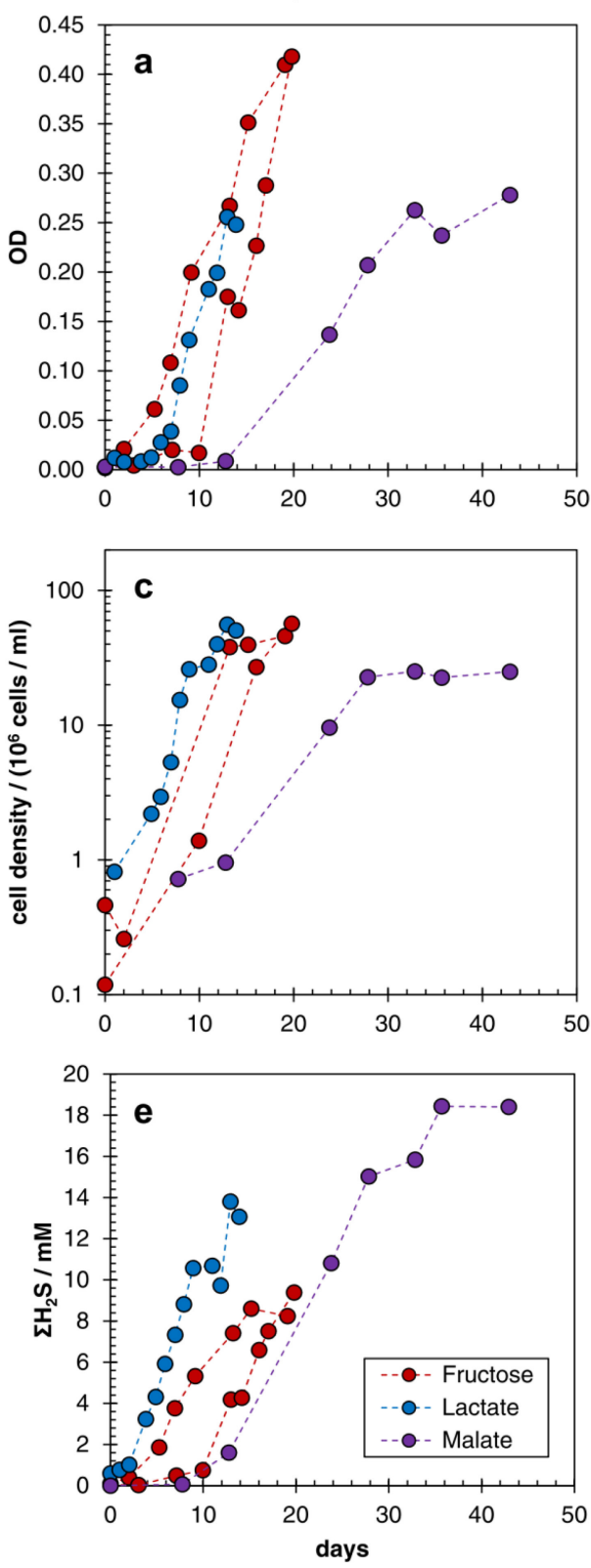

\section{D. fructosovorans}
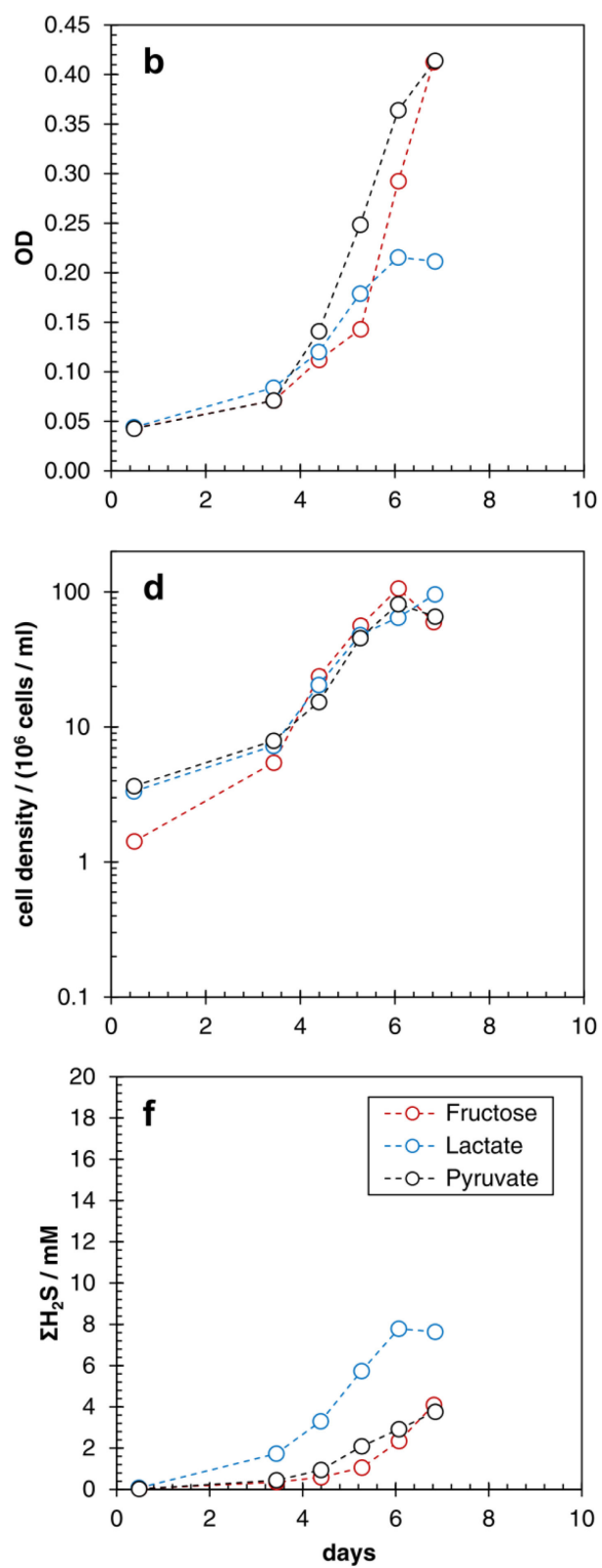

FIGURE A1 | Growth curves showing optical density of cultures (a,b), cell densities determined by epifluorescence microscopy (c,d), and total sulfide $\left(\Sigma \mathrm{H}_{2} \mathrm{~S}\right)$ concentration (e,f) in batch cultures of $D$. inopinatus (left) and $D$. fructosovorans (right) grown on different organic substrates (see the legend for the explanation of color coding) in phosphate-replete $(>1000 \mu \mathrm{M})$ media. Data are from Table 2. Note the difference in scales for the time axis between left and right panels. The uncertainties in cell density and sulfide concentration, respectively, were $\pm 15 \%$ and $\pm 10 \%$, respectively. 


\section{D. inopinatus}
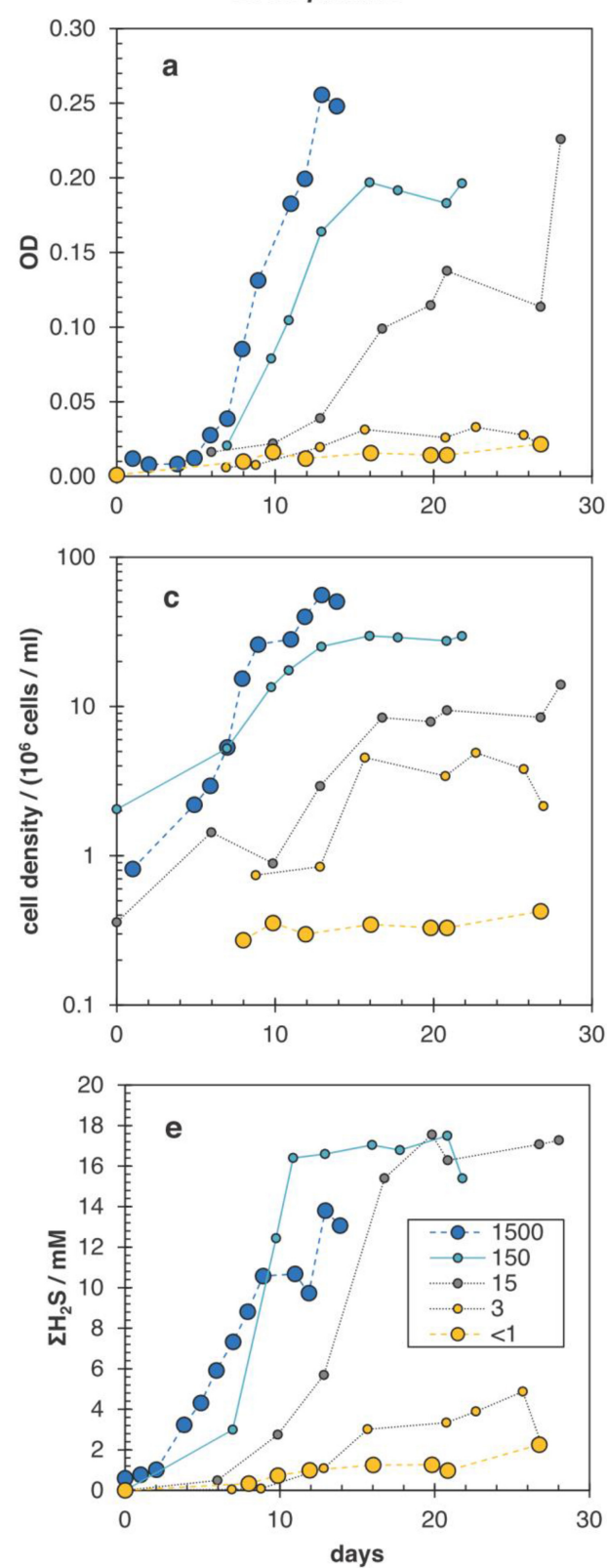

DMSS-1
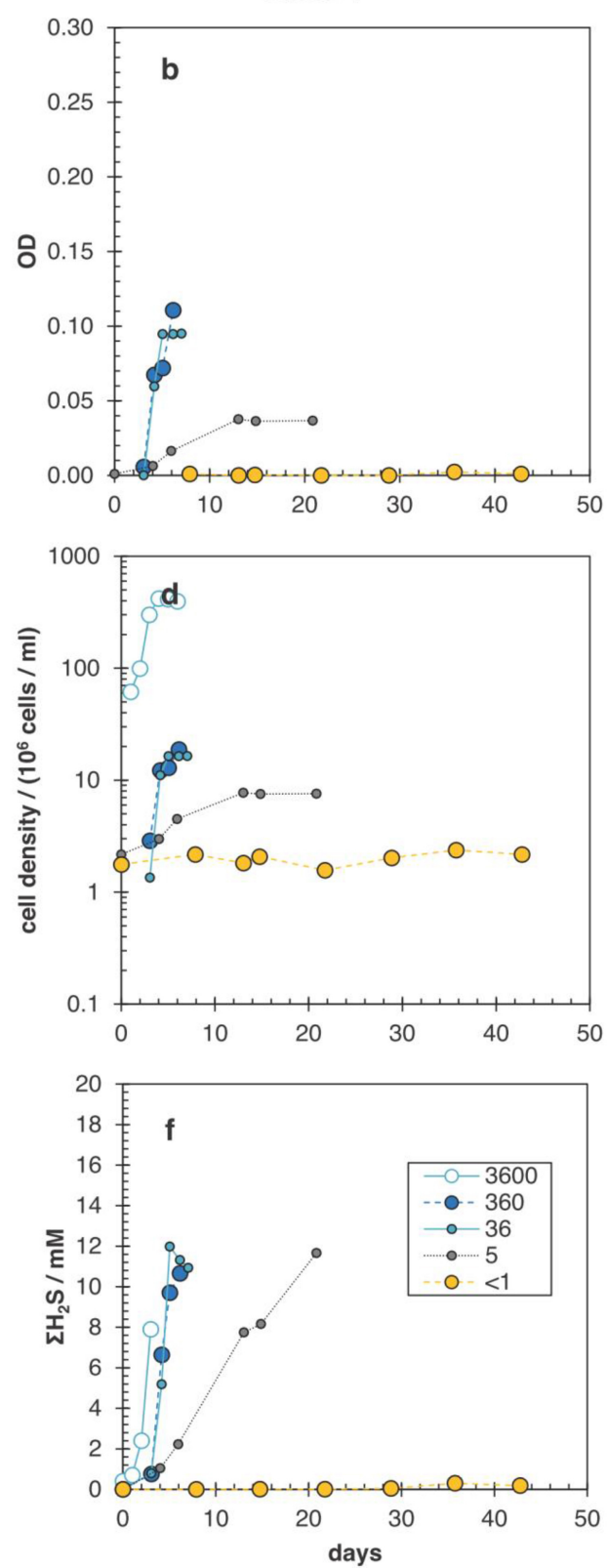

FIGURE A2 | Growth curves showing optical density of cultures (a,b), cell densities determined by epifluorescence microscopy (c, d), and total sulfide $\left(\Sigma \mathrm{H}_{2} \mathrm{~S}\right)$ concentration (e,f) in batch cultures of $D$. inopinatus (left) and DMSS-1 (right) grown on lactate in the presence of different initial phosphate concentrations (in $\mu \mathrm{M}$; legend shown in bottom panels). Data are from Tables 2, 3, with the exception of the data for DMSS-1 cultures grown at $3600 \mu \mathrm{M}$ phosphate (open circles in right panels), which are from Sim et al. (2011b). Note the difference in scales for the time axis between left and right panels. The uncertainties in cell density and sulfide concentration, respectively, were $\pm 15 \%$ and $\pm 10 \%$, respectively. 


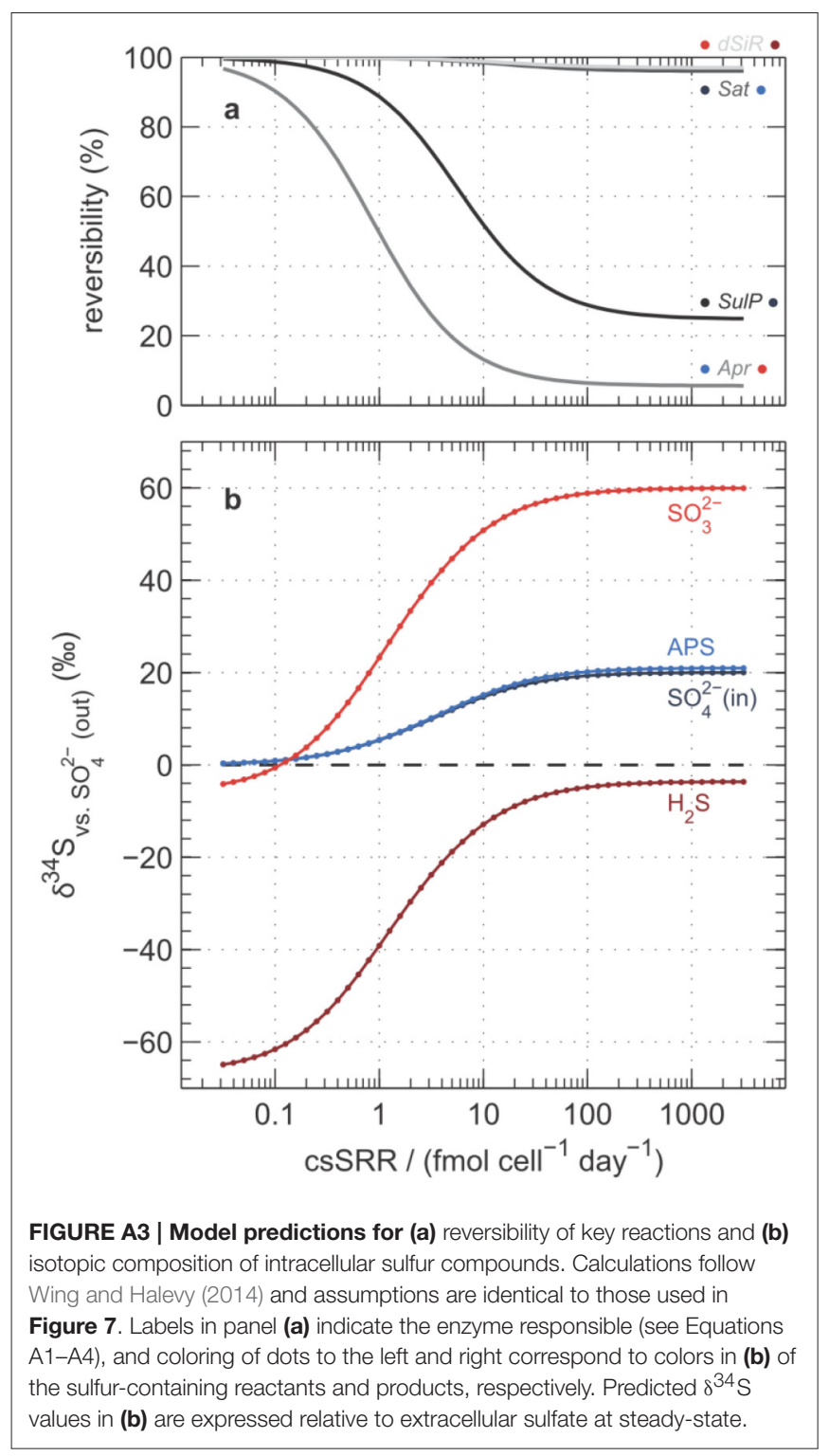




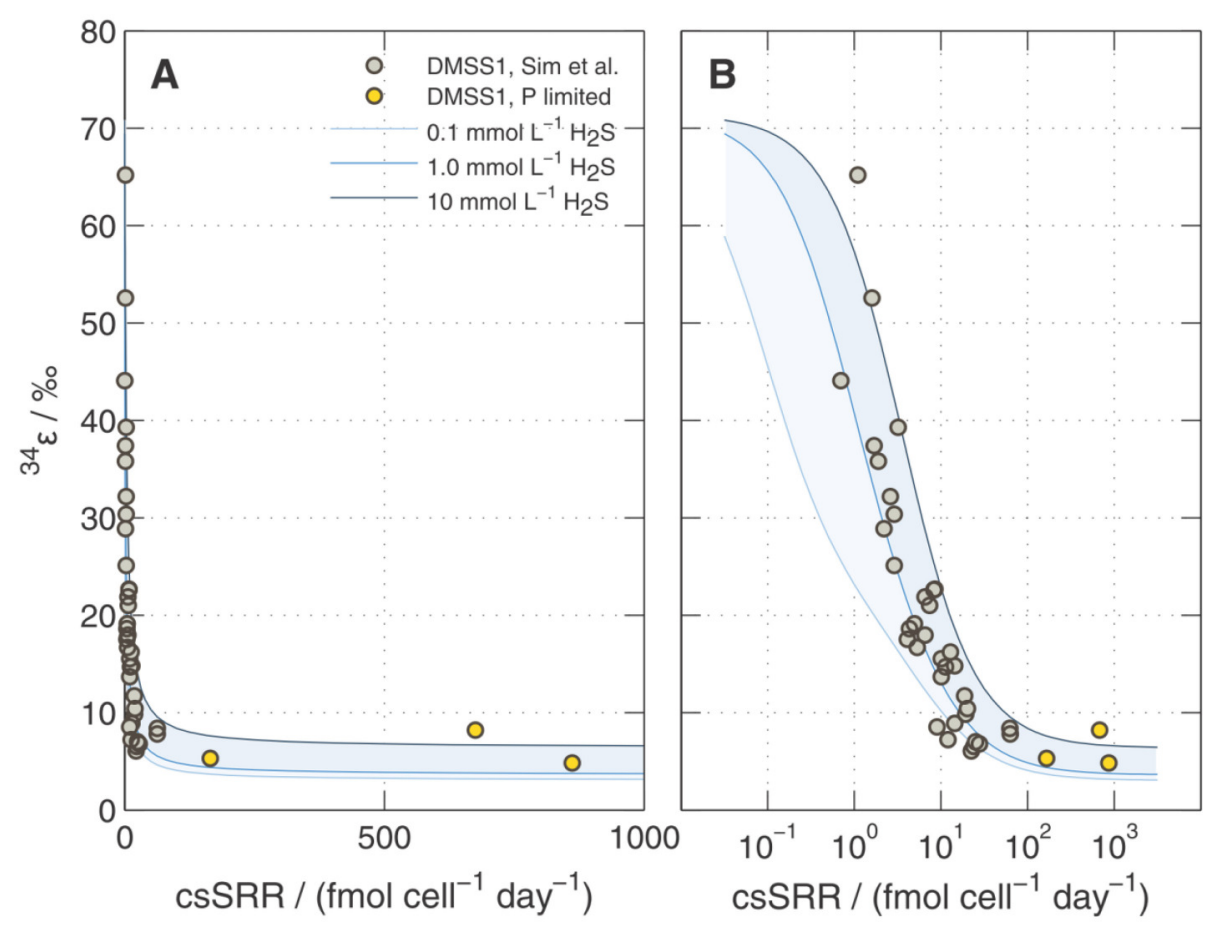

FIGURE A4 | Predicted ${ }^{34} \varepsilon$ during sulfate reduction by DMSS-1 following Wing and Halevy (2014). Calculations are shown for three different $\mathrm{H}_{2} \mathrm{~S}$ concentrations $(0.1,1$, and $10 \mathrm{mM})$ keeping $\left[\mathrm{SO}_{4}^{2-}\right.$ ] out constant at $20 \mathrm{mM}$. Overlaid on the model results are the data shown in Figure $\mathbf{6}$. Panels $(\mathbf{A})$ and $\mathbf{( B )}$ show the same information but with linear and logarithmic $\mathrm{x}$-axis scales (respectively). 